\title{
Palaeoclimatic Information from Stable Water Isotopes of Holocene Ice Wedges on the Dmitrii Laptev Strait, Northeast Siberia, Russia
}

\author{
Thomas Opel, ${ }^{1,2 *}$ Alexander Yu. Dereviagin, ${ }^{3}$ Hanno Meyer, ${ }^{1}$ Lutz Schirrmeister ${ }^{1}$ and Sebastian Wetterich $^{1}$ \\ 1 Alfred Wegener Institute for Polar and Marine Research, Potsdam, Germany \\ 2 Department of Geography, Humboldt-Universität zu Berlin, Berlin, Germany \\ 3 Faculty of Geology, Moscow State University, Moscow, Russia
}

\begin{abstract}
The stable isotopic composition $\left(\delta^{18} \mathrm{O}, \delta \mathrm{D}, d\right)$ of three Holocene-age ice wedges at the Dmitrii Laptev Strait, Russia (Oyogos Yar coast, $72.7^{\circ} \mathrm{N}, 143.5^{\circ} \mathrm{E}$ ) was studied at high resolution (100 to 200 samples each) in order to develop palaeoclimatic records. AMS ${ }^{14} \mathrm{C}$ ages of organic matter in the ice prove the Late Holocene age of the studied horizontal ice-wedge profiles and indicate syngenetic growth associated with sediment accumulation. Co-isotopic relationships of wedge ice close to the Global Meteoric Water Line point to a good suitability for palaeoclimate studies and all three profiles show similar isotopic features. A general Late Holocene winter warming trend is inferred from $\delta^{18} \mathrm{O}$ data changing from about $-26 \%$ to values of $-23 \%$ o to $-21 \%$, with periods of marked variability superimposed on the trend. This trend is accompanied by a shift in the $d$ excess from $8 \% 0-11 \%$ o to $5 \%$ o $-8 \%$, probably caused by varying proportions of differing moisture sources for precipitation. The highest winter temperatures and an increased influence of regional moisture in recent decades may reflect ongoing Arctic climate change. Copyright (C) 2010 John Wiley \& Sons, Ltd.
\end{abstract}

KEY WORDS: Arctic northeast Siberia; permafrost; ice wedges; stable water isotopes; palaeoclimate; Holocene

\section{INTRODUCTION}

The Arctic is a key region of climate change as it has experienced one of the greatest temperature rises in the $20^{\text {th }}$ and $21^{\text {st }}$ centuries (ACIA, 2005; Trenberth et al., 2007) and further increases and a major reduction in sea ice as well as permafrost warming are predicted for the future (e.g. ACIA, 2005; Christensen et al., 2007; Lemke et al., 2007). The Arctic itself influences the global climate system by changes in surface albedo and ocean currents as well as by potential carbon release from thawing permafrost. Understanding the ongoing climate change and improving climate predictions requires detailed information about past changes. But most direct meteorological observations started mostly in the $20^{\text {th }}$ century and only a few records extend back into the $19^{\text {th }}$ century (e.g. Polyakov et al., 2003). Therefore, palaeocli-

\footnotetext{
* Correspondence to: Thomas Opel, Alfred Wegener Institute for Polar and Marine Research, Telegrafenberg A43, 14473 Potsdam, Germany. E-mail: thomas.opel@awi.de
}

Contract/grant sponsor: NaFöG, State of Berlin, Germany. matic archives are needed for the reconstruction of past climate variations.

This study focuses on sites in the vicinity of the Dmitrii Laptev Strait, northeast Siberia, Russia $\left(72.7^{\circ} \mathrm{N}, 143.5^{\circ} \mathrm{E}\right.$; Figure 1). Unlike the central Russian Arctic, where several records from ice cores (Severnaya Zemlya, e.g. Opel et al., 2009; Franz Josef Land, Henderson, 2002), lake sediments (Severnaya Zemlya, Raab et al., 2003; Taimyr Peninsula, e.g. Andreev et al., 2003) as well as tree rings (Taimyr Peninsula, e.g. Naurzbaev et al., 2002) provide palaeoclimatic information for the last centuries to millennia, such archives do not exist (ice cores, tree rings) or are less available (lake sediments) for the study region. However, ice wedges represent a potential source of palaeoclimatic information that is exploited in this study.

Northeast Siberia is characterised by ice-rich permafrost deposits that provide a palaeoclimate archive, including palaeoecological proxies such as pollen (e.g. Andreev et al., 2009), ostracods (e.g. Wetterich et al., 2009), chironomids (e.g. Ilyashuk et al., 2006) and plant macro fossils (e.g. Kienast et al., 2007). The frozen ground contains several different types of ground ice (van Everdingen, 1998, revised 2005). Since ground ice is mostly fed by precipitation, the 


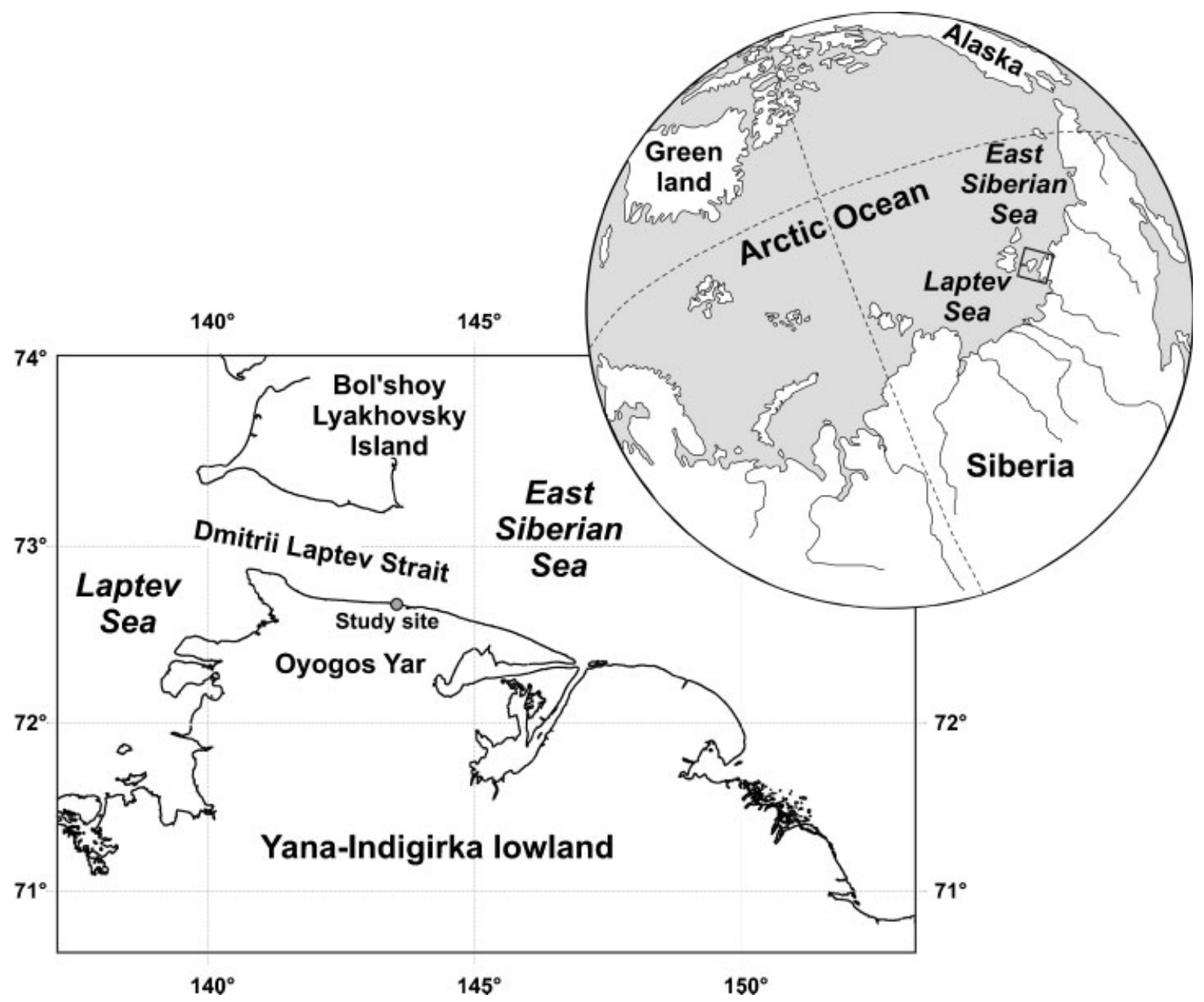

Figure 1 Overview map of the study site on the Oyogos Yar coast of the Dmitrii Laptev Strait.

stable water isotope composition can be used for palaeoclimatic reconstructions (Vaikmäe, 1989). Ice wedges are the most abundant type of ground ice in the ice-rich permafrost deposits of northeast Siberia and the most suitable ground ice type for such stable isotope-based palaeoclimatic studies (e.g. Vaikmäe, 1989; Vasil'chuk, 1991, 1992).

In the last decade, ice wedges in the Laptev Sea region in northeast Siberia have been used in a variety of RussianGerman cooperative palaeoclimate studies. These stable isotope-based studies focused on modern ice-wedge growth (Dereviagin et al., 2002) as well as on the classification and interpretation of different ice-wedge generations, and have been used to produce an overview of winter temperature trends for the last $60 \mathrm{ka}$ (Meyer et al., 2002a, 2002b, unpublished data).

Following a pilot study in 2002 (Schirrmeister et al., 2003), various palaeoclimatological, palaeoecological and sedimentological investigations were carried out on the Oyogos Yar coast of the Dmitrii Laptev Strait within the scope of the joint Russian-German expedition 'Lena - New Siberian Islands' in August 2007 (Schirrmeister et al., 2008). One of the approaches to gain palaeoclimatic information was to study ice wedges of different sedimentological and geochronological units. In this paper, we present stable isotope data of Holocene and recent ice wedges, whereas Pleistocene ice wedges of different stratigraphical units will be the subject of an upcoming study. Here, we focus on the detection and interpretation of isotopic variability, comparison with other regional ice-wedge data and on palaeoclimatic implications.

\section{ICE WEDGES AND STABLE ISOTOPES}

Polygonal ice-wedge formation is based on a combination of frost cracking and freezing processes. In winter, frost cracking occurs in the upper permafrost layers due to thermal contraction caused by rapid cooling at very low temperatures (Lachenbruch, 1962), mostly between midJanuary and mid-March (Mackay, 1974). In spring, elementary ice veinlets form when snow-melt water trickles down into the frost cracks and refreezes there. Periodic repetitions of these cracking-freezing cycles, preferentially near the centre of the ice wedge and often at the same 
location, lead to gradual horizontal ice-wedge growth, even though crack frequency may vary considerably (Mackay, 1974, 1992).

The stable water isotope composition of precipitation is determined by several fractionation processes. However, due to their dependence on condensation temperatures, the stable isotope ratios $\delta^{18} \mathrm{O}$ and $\delta \mathrm{D}$ are commonly accepted as proxies for local to regional-scale temperatures in polar latitudes (e.g. Rozanski et al., 1993). The deuterium excess $d$ $\left(d=\delta \mathrm{D}-8 \delta^{18} \mathrm{O}\right)$, introduced by Dansgaard (1964), reflects evaporation conditions in the moisture source region. Stable water isotope ratios, such as those from ice cores (e.g. North Greenland Ice Core Project (NorthGRIP) Members, 2004), are widely used for palaeoclimate reconstructions. It is generally accepted that melting of snow is the main source for wedge ice (Mackay, 1983; Vaikmäe, 1989; Vasil'chuk, 1991, 1992). Consequently, the stable water isotope composition of ice wedges can be interpreted as a proxy for past winter temperatures and can be used for the reconstruction of palaeotemperature trends as well as of moisture generation and transport patterns (Meyer et al., 2002a, 2002b). According to Michel (1982), meltwater in a frost crack refreezes rapidly enough to prevent fractionation. An elementary ice vein represents the refrozen precipitation of a discrete winter and preserves therefore its specific isotope signal. Assuming regular frost cracking and subsequent formation of an elementary ice vein, ice wedges should contain a continuous stable isotope time series. Studies by Vasil'chuk (1992) and Nikolayev and Mikhalev (1995) have shown that stable isotope ratios of ice wedges can be correlated with mean winter and January temperatures.

\section{STUDY REGION}

Oyogos Yar is the southern coast of the Dmitrii Laptev Strait, which connects the Laptev and East Siberian seas and divides Bol'shoy Lyakhovsky Island from the Eurasian mainland (Figure 1). The coasts of the Dmitrii Laptev Strait have been of geographical and geological interest since the $19^{\text {th }}$ century (e.g. Bunge, 1887; von Toll, 1895), but detailed geocryological and palaeoenvironmental studies on the Oyogos Yar coast started after 1950 (e.g. Gravis, 1978; Konishchev and Kolesnikov, 1981).

This region forms the northern part of the Yana-Indigirka lowland and is part of the continuous permafrost zone. Permafrost thicknesses reach 400 to $600 \mathrm{~m}$, the mean annual ground temperature is about -12 to $-14^{\circ} \mathrm{C}$ (Yershov, 1989) and the mean thickness of the active layer is about $40 \mathrm{~cm}$. Frozen sediments of different ages and accumulation types are exposed in steep bluffs along the coasts of the Dmitrii Laptev Strait and have been the subject of several palaeoclimatological and palaeoecological investigations (e.g. Andreev et al., 2009; Wetterich et al., 2009).

The study area climate is characterised by long severe winters and short cold and rainy summers. Based on data from the nearest meteorological stations at Cape Shalaurova and Cape Kigilyakh (both at Bol'shoy Lyakhovsky Island), and Cape Svyatoy Nos (west of Oyogos Yar), the mean annual air temperature at Oyogos Yar is about $-15^{\circ} \mathrm{C}$, with mean winter and summer temperatures of about $-21.5^{\circ} \mathrm{C}$ and $1.5^{\circ} \mathrm{C}$, respectively. The mean annual precipitation is about $150-200 \mathrm{~mm}$ with more than 60 per cent falling in the summer season. Snow accumulation starts in SeptemberOctober and reaches its mean maximum depth of about 20$25 \mathrm{~cm}$ in spring.

The physiography of the Oyogos Yar coastal region is characterised by an alternation of wide thermokarst depressions (alases) and hills representing remnants of Ice-Complex materials (Yedoma). Thermokarst depressions can be up to $5-10 \mathrm{~km}$ in diameter and have flat bottoms with numerous ponds and small thermo-erosional valleys with creeks and brooks. The alas surface is characterised by nets of ice-wedge polygon systems with diameters of 10 to $20 \mathrm{~m}$. The alas bottoms reach elevations of about $8-12 \mathrm{~m}$ a.s.l., while the adjacent Ice-Complex hills rise to about $40 \mathrm{~m}$ a.s.l. A typical sediment sequence of alas exposures studied (Figure 2) can be divided into three parts (Wetterich et al., 2009). Taberal (thawed and refrozen) Weichselian IceComplex deposits are overlain by lacustrine sediments with ice-wedge casts of the Late Glacial and Holocene alas stage. These in turn are covered by a characteristic peat horizon and higher up by boggy deposits, all consisting dominantly of poorly sorted silt with peat inclusions and plant detritus (Figure 2).

\section{MATERIAL AND METHODS}

\section{Sampling and Field Measurements}

After an overview survey along the coastal bluff which cuts the thermokarst depression, we selected the ice wedges to be studied as those having almost perpendicular sections. The steepness of the permafrost outcrops and extensive mudflows limited access to the ice wedges and complicated fieldwork. Before sampling, we described, photographed and sketched the ice wedges. In total, we studied eight Holocene ice wedges; in addition, we studied the most recent part of three of them separately, and only the recent parts (recent ice veins indicating modern growth) of six other wedges.

The ice wedges were sampled using a chain saw, a special ice screw (diameter $15 \mathrm{~mm}$, length $150 \mathrm{~mm}$ ) or an axe, depending on the ice-wedge size and the sampling strategy. We sampled two horizontal high-resolution profiles by chain saw, cutting thin ice slices (about $2-3 \mathrm{~cm}$ ). After cutting, the samples were cleaned to prevent contamination. The icewedge samples $(\mathrm{N}=292)$ were melted on site. For stable isotope analyses, meltwater was stored in 30-ml PE bottles, which were completely filled and tightly closed to avoid evaporation. We collected organic material contained in the melted samples (plant remains, lemming coprolites) for age determination $\left({ }^{14} \mathrm{C}\right.$ AMS $)$. From selected samples meltwater was taken for chemical analyses. A part was filtered and 


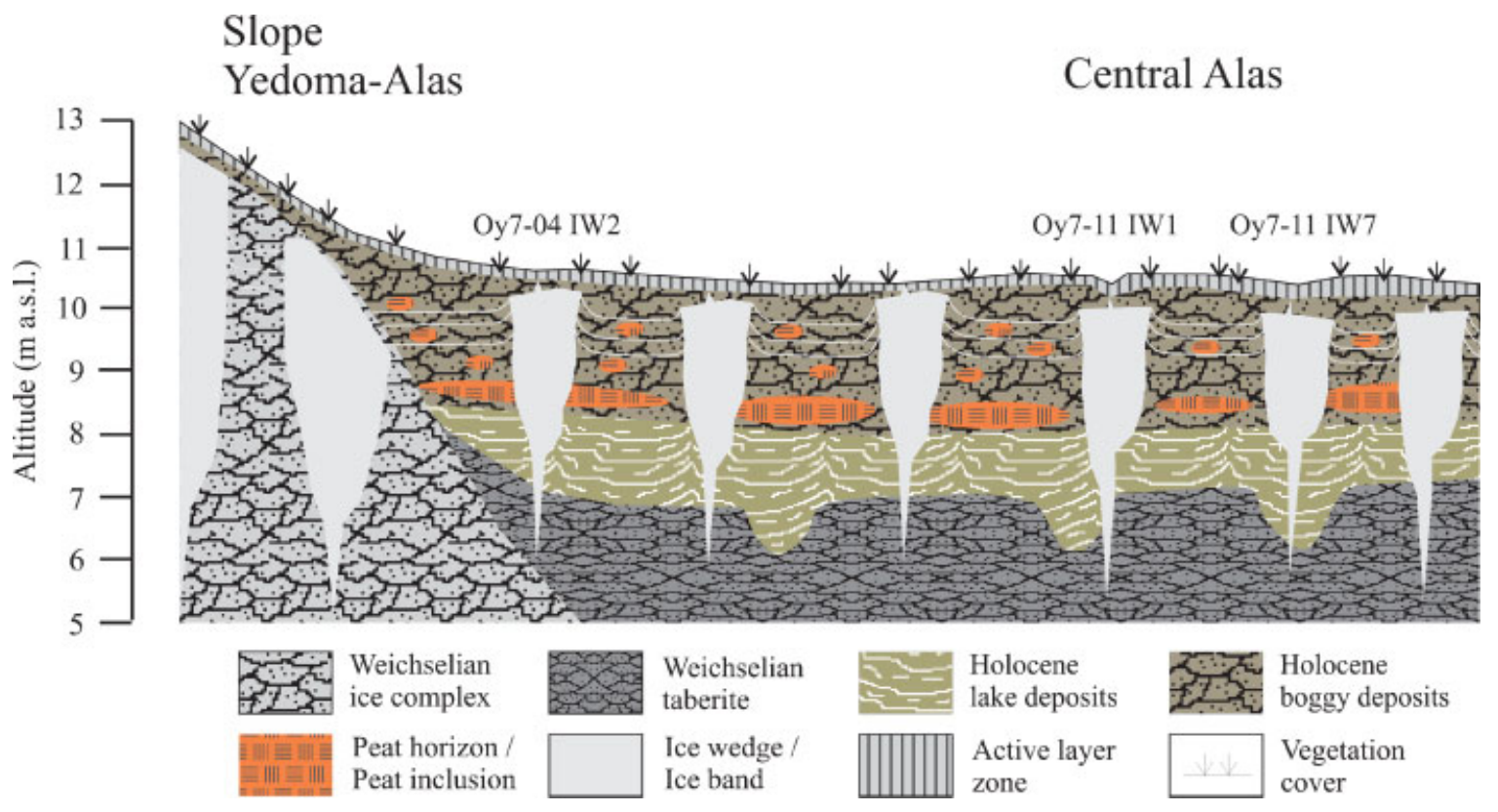

Figure 2 General stratigraphic situation of the Oyogos Yar study site with alas depression and slope to the Yedoma hill. The approximate locations of the studied ice wedges are shown. This figure is available in colour online at www.interscience.wiley.com/journal/ppp.

collected in 8-ml and 15-ml HDPE flasks for measurements of anion and cation concentrations, respectively. We determined $\mathrm{pH}$ and electrical conductivity (EC) in the field camp with a handheld multi-parameter instrument (WTW 340i) equipped with appropriate sensors (pH: SenTix 41; EC: Tetracon 325).

For a third high-resolution profile, we cut blocks (length ca. $20-25 \mathrm{~cm}$ ) from the ice wedge, and transported them in a frozen state to the Alfred Wegener Institute (AWI) Potsdam where they were sampled in a cold room.

Additionally, fresh precipitation samples $(\mathrm{N}=33)$ as well as samples of snow patches from the preceding winter $(\mathrm{N}=2)$ were collected for measurement of stable isotopes and stored in the same way as the ice-wedge samples.

\section{Laboratory Methods}

For all samples, the oxygen $\left(\delta^{18} \mathrm{O}\right)$ and hydrogen $(\delta \mathrm{D})$ stable isotope ratios were analysed at the stable isotope laboratory of AWI Potsdam using a Finnigan MAT Delta-S mass spectrometer. Both isotope ratios were determined for the same water sample using equilibration techniques. The values are expressed in delta per mil notation $(\delta, \%)$ relative to the Vienna Standard Mean Ocean Water (VSMOW). The analytical precision is better than $\pm 0.1 \%$ for $\delta^{18} \mathrm{O}$ and $\pm 0.8 \%$ for $\delta \mathrm{D}$ (Meyer et al., 2000).

Plant remains of selected ice-wedge samples were radiocarbon-dated using the AMS facilities at the Leibniz Laboratory for Radiometric Dating and Stable Isotope Research (Kiel University, Germany). Details of the AMS facility in Kiel were published by Nadeau et al. (1997, 1998). Conventional ${ }^{14} \mathrm{C}$ ages were calculated according to
Stuiver and Polach (1977). For the determination of calibrated ages, the IntCal04 data set (Reimer et al., 2004) was used.

Selected ice-wedge samples were analysed for ion concentrations in the hydrochemistry lab of AWI Potsdam. The anion concentrations were determined by means of ion chromatography (Dionex-320), whereas cation concentrations were analysed using inductively coupled plasma optical emission spectrometry (Perkin-Elmer Optima $3000 \mathrm{XL})$.

\section{ISOTOPIC COMPOSITION OF RECENT PRECIPITATION}

Samples from all precipitation events as well as from snow patches were used to characterise the modern stable water isotope environment of the study region (Figure 3). Due to the late-summer field season, only two snow-patch samples could be collected from deep cracks along the coastal cliff, whereas numerous rain samples were obtained during the four weeks of fieldwork (Table 1).

The rain samples $(\mathrm{N}=33)$ exhibited $\delta^{18} \mathrm{O}$ values between $-20.2 \%$ and $-11.7 \%$ and $\delta \mathrm{D}$ values between $-147.5 \%$ and $-85.4 \%$, with mean values of $-15.8 \%$ and $-119.0 \%$, respectively (Table 1 ). The $d$ excess varied between $-0.2 \%$ and $15.1 \%$, with a mean of $7.3 \%$. The co-isotopic relationship as displayed in the $\delta^{18} \mathrm{O}-\delta \mathrm{D}$ diagram (Figure 3) is $\delta \mathrm{D}=7.16 \delta^{18} \mathrm{O}-6.0\left(\mathrm{R}^{2}=0.96\right)$, which deviates from the Global Meteoric Water Line (GMWL), theoretically defined as $\delta \mathrm{D}=8 \delta^{18} \mathrm{O}+10$ (Craig, 1961) and calculated on a global scale as $\delta \mathrm{D}=8.17 \delta^{18} \mathrm{O}+10.35$ 
Palaeoclimatic Information from Stable Isotopes of Holocene Ice Wedges

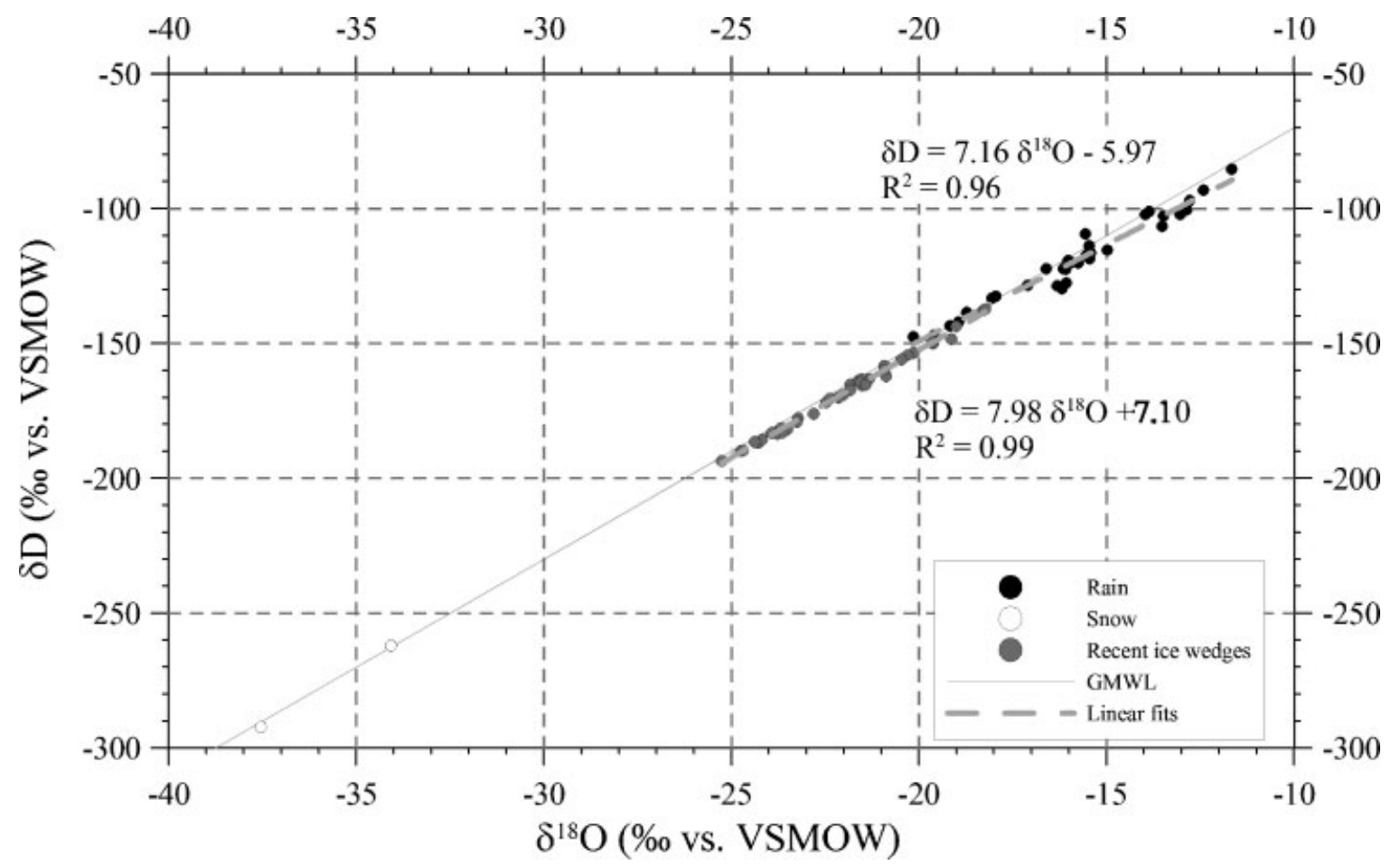

Figure $3 \delta^{18} \mathrm{O}-\delta \mathrm{D}$ diagram for samples of snow patches, rain water and recent ice wedges. VSMOW, Vienna Standard Mean Ocean Water; GMWL, Global Meteoric Water Line.

(Rozanski et al., 1993). However, Meyer et al. (2002b) found a similar slope of 6.8 for Bol'shoy Lyakhovsky Island summer precipitation. The deviation from the GMWL as well as the highly variable $d$ excess point to kinetic fractionation processes for summer precipitation. These processes may be connected with the mixing of air masses bearing moisture from sources that differ isotopically from the North Atlantic Ocean, the assumed main moisture source (Kuznetsova, 1998). Presumably, such moisture originates from recycled water (i.e. evaporated from continental tundra ponds and lakes as well as from the active layer). As shown by Kurita et al. (2004), the isotopic composition of precipitation in Siberia is largely influenced by such recycling of continental water. Evaporation from the icefree Laptev and East Siberian seas could increase the proportion of regional moisture. Generation of this moisture proportion at relatively cold temperature conditions might lead to lower $d$-excess values, as similarly deduced for the Akademii Nauk ice core (Severnaya Zemlya, Opel et al., 2009). Due to its position relatively close to the Pacific Ocean, Pacific moisture might also contribute to precipitation reaching the study region.

The snow-patch samples, as indicators of winter precipitation, show very low $\delta^{18} \mathrm{O}$ values of $-37.6 \%$ and $-34.1 \%$ and $\delta \mathrm{D}$ values of $-292.3 \%$ and $-262.0 \%$, with $d$-excess values of $8.1 \%$ and $10.6 \%$ (Table 1 ). The coisotopic relationship of $\delta \mathrm{D}=8.72 \delta^{18} \mathrm{O}+35.26$ is not significant due to the limited sample number $(\mathrm{N}=2)$. However, the $d$-excess values plot close to the GMWL and thus indicate that kinetic fractionation is not great. This is most probably caused by the isolated location of these snow patches, preventing substantial sublimation. The very light isotope values may indicate extreme precipitation events, since they exceed the lower end of the range of snow-patch samples known from Bol'shoy Lyakhovsky Island $\left(\delta^{18} \mathrm{O}\right.$ : $-31.4 \%$ to $-16.1 \%$, mean: $-26.3 \%$; $\delta \mathrm{D}:-239.0 \%$ o to $-125.6 \%$, mean: $-198.7 \%$ ) on the northern shore of the Dmitrii Laptev Strait about $100 \mathrm{~km}$ northwest of our study site (Meyer et al., 2002b). However, east Siberian Arctic winter precipitation exhibits a wide range of stable isotope composition as shown by Kurita et al. (2005) and Kloss (2008). For the Tiksi site southeast of the Lena Delta on the central Laptev Sea coast (about $500 \mathrm{~km}$ west of Oyogos Yar), isotopic data of snow samples collected on a daily basis ranged from $-46.1 \%$ to $-9.7 \%$ (mean: $-28.7 \%$ ) for $\delta^{18} \mathrm{O}$ and $-359.4 \%$ to $-94.3 \%$ (mean: $-225.6 \%$ ) for $\delta \mathrm{D}$ (Kloss, 2008). Therefore, the snow-patch stable isotope data fall within the regional winter isotopic pattern, even though they appear to represent precipitation events that took place at very low temperatures.

\section{ISOTOPIC COMPOSITION OF RECENT ICE WEDGES}

The most recent parts (i.e. ice veins penetrating from the permafrost table into the ice wedge due to modern cracking) of nine ice wedges were sampled to isotopically characterise 
T. Opel et al.

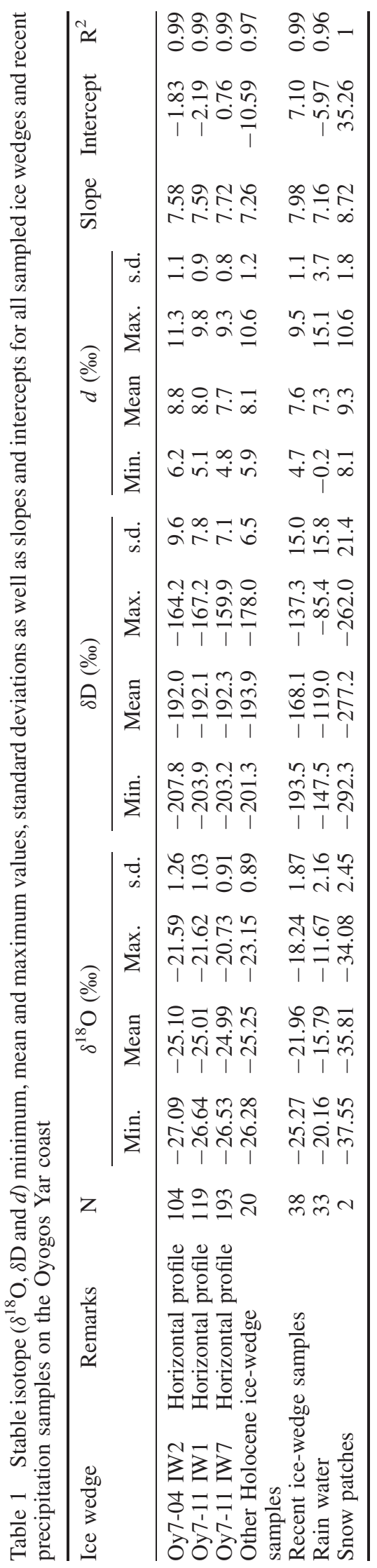

modern ice-wedge growth. Samples were taken from parts extending above the main ice wedge as well as from corresponding parts traced within the actual ice-wedge body (Figure 4). The presence of such recent ice-vein assemblages points to a deeper thaw event during recent decades followed by refreezing. Thawing of part of the transition zone presumably occurred (see Lewkowicz, 1994; Shur et al., 2005), truncating the ice wedges and this layer subsequently refroze. Due to the fieldwork period in late summer we were not able to sample the elementary ice veins of the preceding winter/spring. The assemblages of recent ice veins were between 2 and $8 \mathrm{~cm}$ wide (Figure 4), overtopping the ice wedge by about 10 to $15 \mathrm{~cm}$ and containing six to 30 elementary ice veins, in so far as single veins were distinguishable. Elementary ice veins reached a thickness of up to $3 \mathrm{~mm}$, but most ranged between 0.5 and $2 \mathrm{~mm}$. These recent veins consisted mostly of white, milky ice characterised by numerous small air bubbles and some mineral inclusions, but clear ice veins were also visible. In total, 38 samples were collected from such recent ice veins or ice wedges.

The isotopic composition of recent ice wedges ranges from $-25.3 \%$ to $-18.2 \%$ (mean: $-22.0 \%$ ) for $\delta^{18} \mathrm{O}$ and from $-193.5 \%$ to $-137.3 \%$ (mean: $-168.1 \%$ ) for $\delta \mathrm{D}$ (Table 1). As expected, the $\delta$ values are located between the extreme winter and summer precipitation data (Figure 3), but relatively close to the summer samples. Probably, recent frost cracks were fed by meltwater from later stages of snow melt, characterised by a heavier isotopic composition compared to the initial snow (Lauriol et al., 1995; Meyer et al., 2002b). Due to the limited number and extremely light winter samples, it was not possible to connect their stable isotope composition directly to that of recent ice wedges. However, the isotope values of recent ice wedges coincide well with recent ice veins at Bol'shoy Lyakhovsky Island $\left(\delta^{18} \mathrm{O}:-22.5 \%\right.$ to $-19.2 \%$, mean: $-20.4 \%$; $\delta \mathrm{D}:-175.5 \%$ o to $-149.2 \%$, mean: $-158.9 \%$ ), which exhibit a connection to winter precipitation (Meyer et al., 2002b; Dereviagin et al., 2002).

In the $\delta^{18} \mathrm{O}-\delta \mathrm{D}$ diagram (Figure 3), recent ice-wedge data of Oyogos Yar display a slope of 7.98 and an intercept of 7.1, parallel to the GMWL. This indicates that the mean isotopic composition of recent ice wedges was not greatly affected by kinetic fractionation during sublimation of snow, meltwater percolation through the snowpack, or by refreezing of meltwater in the frost crack. From this and the similarity of our data to the nearby study site at Bol'shoy Lyakhovsky Island, we conclude that the stable isotope composition of Oyogos Yar recent ice wedges is mainly determined by the mean isotopic composition of winter precipitation. However, $d$-excess values, varying between $4.7 \%$ and $9.5 \%$ (mean: 7.6\%), are slightly shifted below the GMWL. This shift points to the possibility that moisture sources other than the assumed pre-eminent one of the North Atlantic Ocean have contributed to precipitation at Oyogos Yar. Following Kuznetsova (1998), the boundary between prevailing western and eastern flows in Northern Eurasia, transporting Atlantic and Pacific moisture, respectively, is located between $130^{\circ}$ and $150^{\circ} \mathrm{E}$ in winter. Therefore, Pacific 


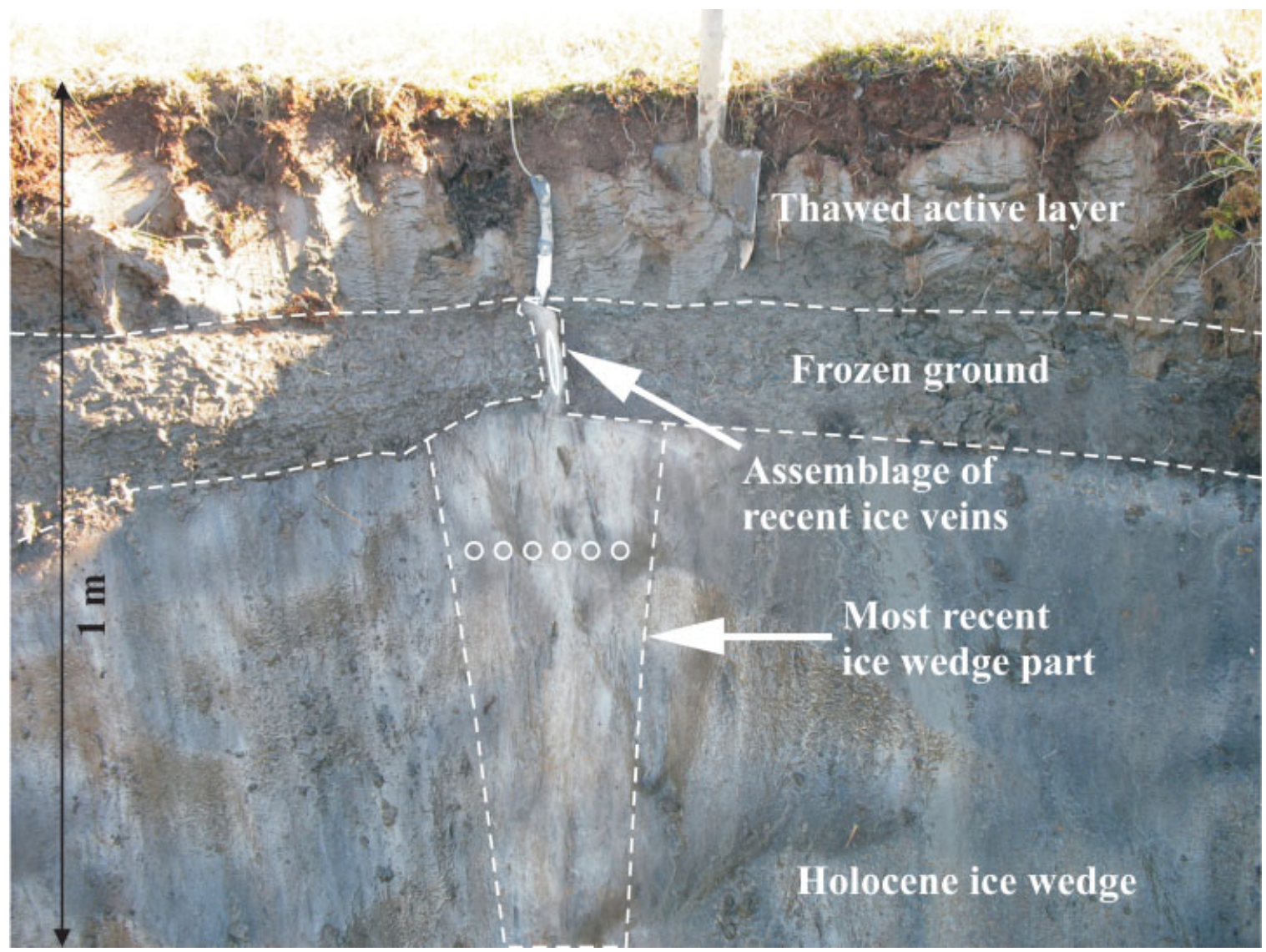

Figure 4 Example of recent ice-wedge growth in ice wedge Oy7-11 IW7 as considered in this study: assemblage of recent ice veins overtopping the ice wedge and corresponding parts located in the actual ice-wedge body. White circles and ellipse mark sample points. This figure is available in colour online at www.interscience.wiley.com/journal/ppp.

moisture could also have contributed to winter precipitation incorporated into ice wedges on the Oyogos Yar coast (Kurita et al., 2005), as could have polynyas (areas of open water) in the generally ice-covered Laptev or East Siberian seas.

\section{HOLOCENE ICE WEDGES}

\section{Description}

The following results are mainly based on high-resolution profiles of three syngenetic ice wedges but consider also samples taken from other Holocene ice wedges. Ice wedge Oy7-04 IW2 was located in the transition zone from the Yedoma-alas slope to the alas bottom, whereas ice wedges OY7-11 IW1 and Oy7-11 IW7 were located in the central alas depression (Figure 2). All the wedges were sampled at the coastal bluff at an elevation of about $10 \mathrm{~m}$ a.s.l. At the level of the sampling profiles, the wedges were enclosed by typical boggy alas deposits: grey silts with varying amounts of clay and sand and some peat inclusions. At the contact zone with the ice wedges, brownish layers were observed.
These sediments were characterised by layered as well as regular to irregular reticulate cryostructures. The vertical separation of single horizontal ice layers $(2-5 \mathrm{~cm}$ thick) was $10-20 \mathrm{~cm}$. Close to the ice wedges the ice layers were bent upwards. In general, the ice wedges were overlain by $35-$ $70 \mathrm{~cm}$ of sediment, mainly grey-brownish silty loams, covered by a layer of peaty soil. Whereas the uppermost 20 $40 \mathrm{~cm}$ of sediments were attributed to the active layer, the frozen transition zone between the ice wedge and active layer accounted for $10-30 \mathrm{~cm}$.

\section{Ice Wedge Oy7-04 IW2.}

Ice wedge Oy7-04 IW2 was about $3.2 \mathrm{~m}$ wide and the visible height was about $1.5 \mathrm{~m}$ (Figure 5a). The lower part of the ice wedge was buried under muddy debris but from better exposed ice wedges nearby we infer that the mean vertical dimension was about 5-6 m. A well-defined group of recent ice veins surmounted the ice wedge in its central part. The ice wedge consisted of white to transparent ice with many vertically oriented air bubbles up to $1 \mathrm{~cm}$ long, especially in the central part. Mineral inclusions and organic matter were present in the generally clean ice. Vertically to subvertically oriented ice veins, each $1-3 \mathrm{~mm}$ thick, were evident within 
T. Opel et al.

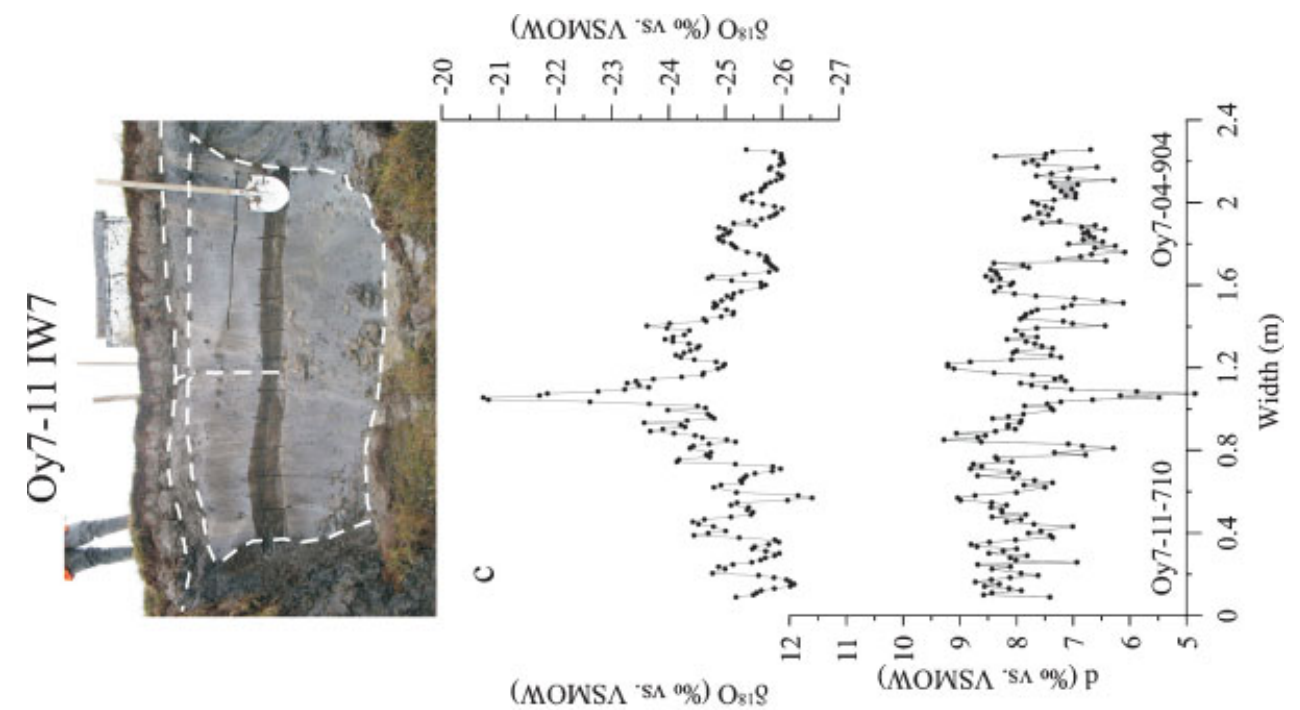

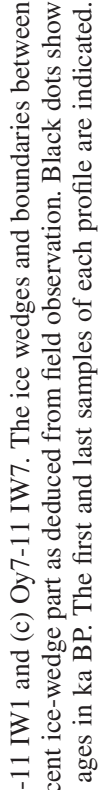

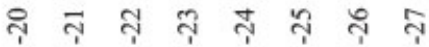

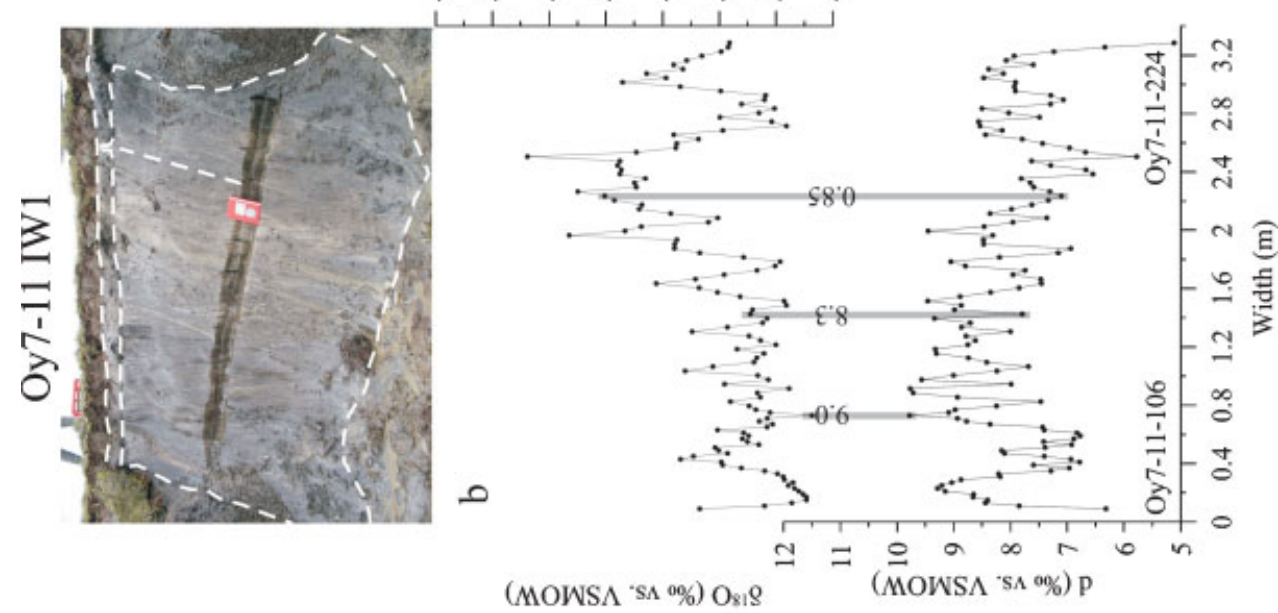

ণิ

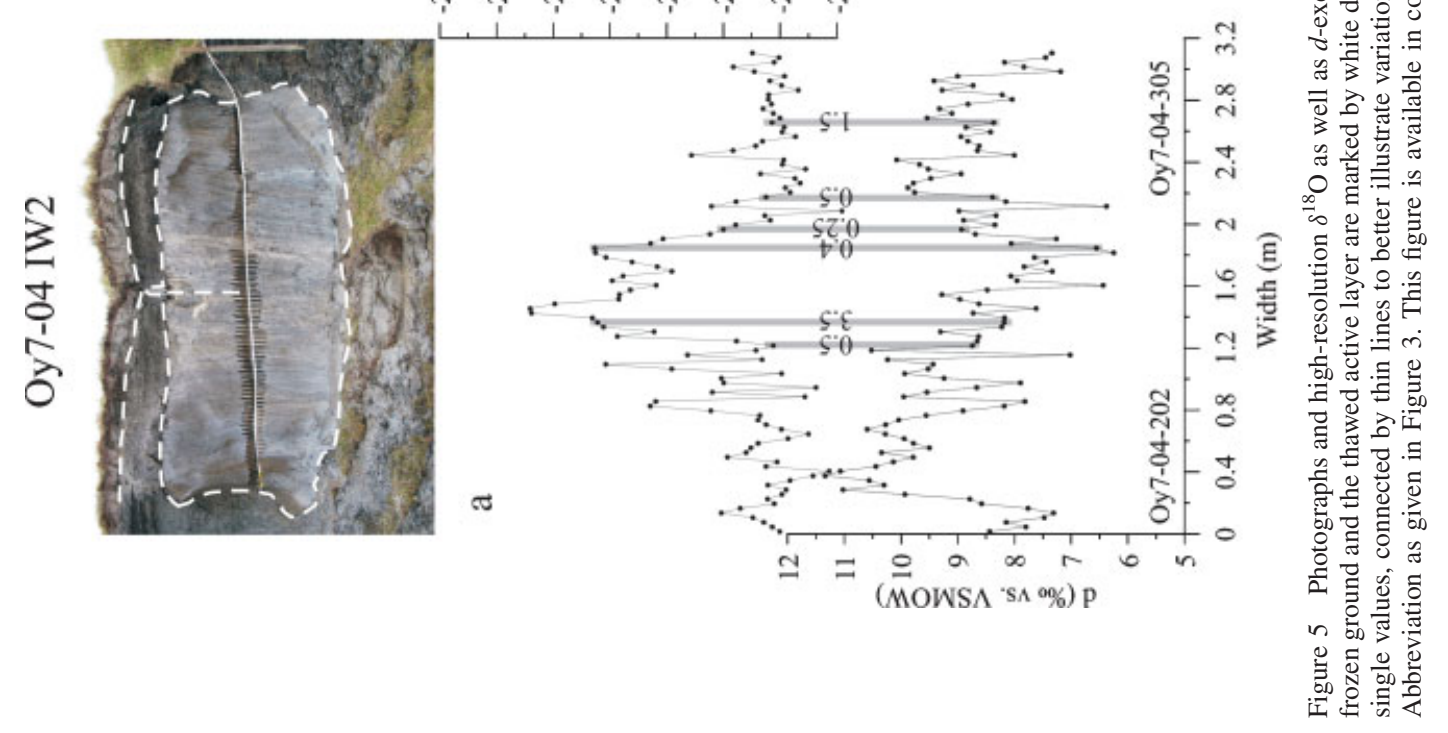


the ice wedge. In total, we collected 107 samples at a resolution of about $2.5 \mathrm{~cm}$ by chainsaw in a horizontal profile at about $1.60 \mathrm{~m}$ below the surface. This profile was perpendicular to the long axis of the ice wedge. The mean values of $\mathrm{EC}$ and $\mathrm{pH}$ were $44 \mu \mathrm{S} / \mathrm{cm}$ and 6.5 , respectively.

\section{Ice Wedge Oy7-11 IWI.}

The ice wedge Oy7-11 IW1 was about $3.5 \mathrm{~m}$ wide. Its bottom part was buried under debris so the visible height was about $2 \mathrm{~m}$ (Figure $5 \mathrm{~b}$ ). The ice wedge was obviously not symmetrically structured, because the most recent ice veins were not located in its centre but 70 to $80 \mathrm{~cm}$ away from the western edge. This might point to imbalanced growth with different ice-wedge generations, interrupted by inactive phases, and/or to a change in orientation of the polygonal system. The ice wedge consisted mostly of greyish dirty ice and was rich in organic and mineral inclusions as well as small vertically oriented gas bubbles. The high-resolution sampling transect was located about $1.5 \mathrm{~m}$ below the surface. In total, we took 123 samples at a resolution of about $2.5 \mathrm{~cm}$. EC and pH exhibited mean values of $58 \mu \mathrm{S} / \mathrm{cm}$ and 6.2 , respectively.

\section{Ice Wedge Oy7-11 IW7.}

The perpendicularly cut ice wedge Oy7-11 IW7 had a width of about $2.5 \mathrm{~m}$ and a visible height of $1.2 \mathrm{~m}$ with a buried lower part (Figure 5c). This ice wedge exhibited a pronounced recent ice-vein assemblage about $3 \mathrm{~cm}$ wide in its centre (Figure 4). These recent ice veins and the central part of the ice wedge were more milky white due to more air bubbles than other parts. Subvertically oriented ice veins were common in the whole ice wedge and individual veins were up to $1 \mathrm{~cm}$ wide. We sampled a horizontal profile $1 \mathrm{~m}$ below the surface and took 12 blocks $(20-25 \mathrm{~cm}$ wide, including the ice-sediment interface at both rims), which were sampled later under cold laboratory conditions in Potsdam at a resolution of $1 \mathrm{~cm}$ (210 stable isotope samples) and $4-5 \mathrm{~cm}$ ( 45 hydrochemistry samples). The mean values of EC and $\mathrm{pH}$ were $40 \mu \mathrm{S} / \mathrm{cm}$ and 6.0 , respectively. No significant differences regarding the major ion concentrations existed among the three high-resolution profiles.

\section{Other Ice Wedges.}

We also took samples from five other Holocene ice wedges which were similar to the ones described above. These samples were taken by ice screw. Except for one, all samples were taken from the middle to lower parts of the ice wedges at elevations of 5 to $7 \mathrm{~m}$ a.s.1.

\section{Chronology}

The dating of ice wedges is crucial for palaeoclimatic interpretation of the derived proxy records. Even though a direct dating method for ground ice was recently developed (Gilichinsky et al., 2007) and successfully applied to different Pleistocene ice-wedge generations (Blinov et al., 2009), ice wedges have commonly been dated indirectly by age determination of enclosing sediments (Meyer et al., 2002a, 2002b), or by direct ${ }^{14} \mathrm{C}$ dating of organic remains within ice wedges (e.g. Vasil'chuk et al., 2000). The latter method is based on the incorporation of organic material of plant (blades of grass, leaves, roots) or animal origin (e.g. lemming coprolites), fallen or moved by meltwater into the open frost crack. This material marks the age of one discrete frost crack-filling event if contamination or reworking of the organic material can be excluded. As recently shown by Meyer et al., (accepted) ${ }^{14} \mathrm{C}$ dating of organic remains in the ice can permit the generation of highresolution (centennial scale) stable isotope time series from ice wedges.

In this study, plant remains in nine samples of ice wedges Oy7-04 IW2 and Oy7-11 IW1 were AMS ${ }^{14} \mathrm{C}$-dated (samples are marked in Figure 5a and b). We present the corresponding ages in Table 2 . The ${ }^{14} \mathrm{C}$ ages reveal the ice wedges to be of Holocene age. These results accord with those of Wetterich et al. (2009) who found Late Glacial ages of 14.8 to $10.7 \mathrm{ka}$ BP for lacustrine alas deposits with age reversals, most probably due to cryoturbation (Table 2). After the thermokarst lake drained, the initial ice wedges may have formed epigenetically. Wetterich et al. (2009) dated the overlying boggy sediments, which contain the studied syngenetic parts of the ice wedges, to 10.0 to $3.3 \mathrm{ka}$ BP with an unconformity between the Early (10 to $8.3 \mathrm{ka}$ BP) and Late Holocene (3.3 ka BP), possibly caused by a phase of erosion or a cessation of sedimentation.

In general, the ${ }^{14} \mathrm{C}$ ages of Holocene ice wedges from Oyogos Yar can be classified into two groups: Early Holocene ( 8 to $9 \mathrm{ka} \mathrm{BP}$ ) and Late Holocene ( 0.25 to $1.5 \mathrm{ka}$ BP). There were no Middle Holocene ages (about 5 to $6 \mathrm{ka}$ BP) in the ice-wedge samples. This is in line with the absence of mid-Holocene alas deposits in recent investigations on the Oyogos Yar coast (Wetterich et al., 2009) as well as on Bol'shoy Lyakhovsky Island (Andreev et al., 2009; Wetterich et al., 2009), whereas a previous study by Gravis (1978) reported such deposits on the Oyogos Yar coast.

Organic material from one sample (Oy7-04-247, dated to $3.5 \mathrm{ka}$ BP, Table 2) was characterised by a low carbon content and was probably derived from reworked plant detritus (Pieter M. Grootes, Leibniz Laboratory for Radiometric Dating and Stable Isotope Research, Kiel University, Germany, personal communication). Therefore, it was excluded from further interpretation.

\section{Ice Wedge Oy7-04 IW2.}

All significant dated samples of ice wedge Oy7-04 IW2 were of Late Holocene age (Table 2; Figure 5a). In keeping with expectations, the youngest samples $(0.25$ to $0.5 \mathrm{ka} \mathrm{BP})$ were from the central part of the ice wedge, whereas the sample dated to $1.5 \mathrm{ka} \mathrm{BP}$ was located closer to its edge. However, a continuous relation between age and distance from the central ice-wedge part towards the rim was not detectable, most probably due to irregular frost cracking, resulting in different frost-crack positions. Additionally, the plant material used for dating could have been retransported at the ground surface or within the active layer before it was deposited within the thermal-contraction cracks. 
T. Opel et al.

Table 2 Radiocarbon AMS ages of plant remains in ice-wedge samples as well as in sediment samples of the studied Oyogos Yar alas.

\begin{tabular}{|c|c|c|c|c|c|}
\hline Sample & Lab. no. & \multicolumn{2}{|c|}{ Uncal. AMS age [a BP] } & Cal. age $(2 \sigma)[\mathrm{a} \mathrm{BP}]$ & Cal. age $(2 \sigma)[\mathrm{a}]$ \\
\hline Oy7-04-242 & KIA 35630 & 525 & \pm 45 & $565-501$ & AD 1385-1449 \\
\hline Oy7-04-263 & KIA 35632 & 410 & \pm 30 & $520-430$ & AD $1430-1520$ \\
\hline Oy7-04-267 & KIA 35633 & 260 & \pm 50 & $469-266$ & AD 1481-1684 \\
\hline Oy7-04-274 & KIA 35634 & 490 & $+60 /-55$ & $566-434$ & AD 1384-1516 \\
\hline Oy $7-11-162$ & KIA 35637 & 8300 & \pm 43 & 9436-9196 & BC 7486-7246 \\
\hline Oy7-11-189 & KIA 35638 & 855 & \pm 45 & $832-686$ & AD $1118-1264$ \\
\hline \multicolumn{6}{|c|}{ Sediment samples (Wetterich et al., 2009) } \\
\hline Oy7-11-14 & KIA 35234 & 3325 & \pm 35 & $3635-3477$ & BC 1685-1527 \\
\hline Oy7-11-12 & KIA 35233 & 8335 & \pm 45 & $9472-9247$ & BC 7522-7297 \\
\hline Oy7-11-10 & KIA 35232 & 8260 & \pm 40 & 9408-9092 & BC 7458-7142 \\
\hline Oy7-11-04 & KIA 35230 & 11995 & \pm 50 & 13984-13748 & BC 12034-11798 \\
\hline
\end{tabular}

The ice-wedge samples are numbered as follows: Oy7 represents Oyogos Yar 2007, the numbers 04 and 11 mark different outcrops. The three-digit numbers are labelled continuously from left to right (see Figure 5a-c). The sediment samples were taken from bottom to top (for details see Wetterich et al., 2009).

Ice Wedge Oy7-11 IWl.

Ice wedge Oy7-11 IW1 contained organic matter of Late Holocene as well as of Early Holocene age (Table 2; Figure 5b). Late Holocene growth corresponding to that of ice wedge Oy7-04 IW2 is shown by the 0.85-ka BP age of sample Oy7-11-189. The organic material (peat) in icewedge samples Oy7-11-138 and Oy7-11-162 (dated to 9 and $8.3 \mathrm{ka} \mathrm{BP}$, respectively) corresponds to the characteristic Early Holocene peat horizon dated to $8.3 \mathrm{ka}$ BP (sample Oy7-11-10, Table 2) in the transitional horizons from lacustrine to boggy deposits (Wetterich et al., 2009). However, this peat horizon was located well below the ice-wedge top and also about $1-1.5 \mathrm{~m}$ below the position of the dated organic material in the ice wedge. Samples Oy711-138 and Oy7-11-162 were taken from the upper part of the ice wedge (about $1.5 \mathrm{~m}$ below surface, Figure $5 \mathrm{~b}$ ), which was growing syngenetically to enclosing sediments. These were clearly of Late Holocene origin as shown by a 3.3-ka BP age (sample Oy7-11-14, Table 2) and typical pollen spectra (Wetterich et al., 2009). As peat in the samples Oy711-138 and Oy7-11-162 was incorporated into the ice wedge during crack-filling events, it must be relocated material from the Early Holocene peat layer. A redistribution of parts of this horizon (e.g. due to cryoturbation processes) is revealed by sample Oy7-11-12 (Table 2) located about $1 \mathrm{~m}$ above the peat layer and dated to $8.3 \mathrm{ka} \mathrm{BP}$ (Wetterich et al., 2009). Consequently, we consider these Early Holocene ages as being on relocated material and exclude them from palaeoclimatic interpretation.
Ice Wedge Oy7-11 IW7.

No AMS ${ }^{14} \mathrm{C}$ ages on organic remains in this ice wedge are available at present. However, since this ice wedge is in a similar stratigraphic situation but is narrower than ice wedges Oy7-04 IW2 and Oy7-11 IW1, we assume a Late Holocene age or younger for the sampled profile of this ice wedge.

Assuming a temporal mean frost-cracking frequency of 50 per cent (Mackay, 1992) and a mean elementary ice-vein thickness of $2 \mathrm{~mm}, 2.5$ to $3.5 \mathrm{~m}$-wide ice wedges could grow in about 2500 to 3500 years. Consequently, we infer only Late Holocene ice-wedge growth at the position of the icewedge profiles studied at the Oyogos Yar alas. However, an initial stage of epigenetic ice-wedge growth may have occurred at greater depths, even in the Early Holocene directly after drainage of the thermokarst lake. Late Holocene ice-wedge growth, mainly in the last millennium, in thermokarst depressions, thermo-erosional valleys and fluvial terraces has also been described from study sites on Bol'shoy Lyakhovsky Island (Meyer et al., 2002b), the Bykovsky Peninsula (Meyer et al., 2002a), at Cape Mamontov Klyk (Meyer et al., unpublished data) and the Lena Delta (H. Meyer, unpublished data).

\section{Isotopic Composition and Palaeoclimatic Implications}

To obtain a pure ice-wedge signal, we excluded some of the outermost samples that extended beyond the ice-sediment 
interface as well as samples exhibiting a clearly modified isotopic composition due to water migration between the ice wedge and enclosing sediments (Meyer et al., 2002a). Such samples were observed only in the outermost 2 to $3 \mathrm{~cm}$ of the ice wedge. They had distinctly increased $\delta^{18} \mathrm{O}$ values (about $2 \%$ to $7 \%$ higher) and extremely low $d$-excess values $(-7 \%$ o to $5 \%$ ) compared to the adjacent, presumably unaffected ice-wedge samples. Assuming an exchange rate between the ice wedge and surrounding sediments of about $10-15 \mathrm{~cm}$ per 10000 years (Meyer et al., unpublished data), the small number of affected samples indicates a relatively young age of the studied ice wedges, supporting the expected Late Holocene age. Accordingly, we used 104 out of 107 samples from ice-wedge profile Oy7-04 IW2, 119 out of 123 from Oy7-11 IW1, 193 out of 210 from Oy7-11 IW7 and 20 out of 24 from other Holocene ice-wedge samples.

The stable isotopic composition of the three highresolution ice-wedge profiles is summarised in Table 1. The scatter of these data is displayed in $\delta^{18} \mathrm{O}-\delta \mathrm{D}$ diagrams (Figure $6 \mathrm{a}-\mathrm{c}$ ). The minimum, maximum and mean values for $\delta^{18} \mathrm{O}, \delta \mathrm{D}$ and $d$ excess, as well as the slopes (7.58 to 7.72) and intercepts $(-2.19$ to 0.76$)$ in the $\delta^{18} \mathrm{O}-\delta \mathrm{D}$ diagrams are very similar to each other and relatively close to the GMWL as well as to recent ice-wedge data, pointing to only minor influence of kinetic fractionation processes. The $d$-excess values (about $8 \%$ ) are also close to the GMWL. The coisotopic relationships of the high-resolution profiles can therefore be regarded as a reliable Late Holocene LMWL (Local Meteoric Water Line) for winter precipitation on the Oyogos Yar coast. Thus, climate-relevant data are obtainable from these ice wedges.

Other Holocene ice-wedge samples, taken mainly from lower parts of several ice wedges around the characteristic peat layer ( 3 to $5 \mathrm{~m}$ below the surface), differ slightly. Whereas the mean values of $\delta^{18} \mathrm{O}, \delta \mathrm{D}$ and $d$ excess are close to those of the high-resolution profiles, the slope (7.26) as well as the intercept $(-10.59)$ are somewhat lower (Figure 6d; Table 1). These samples probably represent an earlier stage of ice-wedge formation when climate conditions were slightly different, and kinetic fractionation processes were involved (such as the mixing of air masses and moisture from different sources or evaporation/ sublimation of snow). However, their isotopic composition corresponds well with data from generally comparable alas ice wedges from nearby Bol'shoy Lyakhovsky Island (Meyer et al., 2002b), which also included samples from lower and therefore older ice-wedge parts.

In the following, we focus on $\delta^{18} \mathrm{O}$, since this isotopic ratio is commonly used in Arctic and Siberian palaeoclimate studies. Despite the similarity in means, maxima and minima, the stable isotope data do have differing $\delta^{18} \mathrm{O}$ distributions (Figure 7). The $\delta^{18} \mathrm{O}$ class $-25 \%$ to $-25.99 \%$ contains the highest proportion $(41-50 \%)$ of $\delta^{18} \mathrm{O}$ values for all three isotope profiles but the $\delta^{18} \mathrm{O}$ class $-26 \%$ to $-26.99 \%$ represents 24 per cent of Oy7-04 IW2 data, and only 14 per cent and 6 per cent of Oy7-11 IW1 and Oy7-11 IW7, respectively. In turn, the $\delta^{18} \mathrm{O}$ class $-24 \%$ to $-24.99 \%$ contains only 11 per cent of Oy7-04 IW2 data, but
24 per cent and 34 per cent of Oy7-11 IW1 and Oy7-11 IW7, respectively. This pattern may be caused by the timing of frost cracking and ice-wedge growth as well as by the location of ice wedges within the thermokarst depression (Figure 2): Oy7-04 IW2 was located close to the slope to the Yedoma hill, whereas Oy7-11 IW1 and Oy7-11 IW7 were situated in the central part. In relation to the $-23 \%$ o to $-23.99 \% \delta^{18} \mathrm{O}$ class, ice wedges Oy7-04 IW2 and Oy7-11 IW1 exhibit twice as high a percentage (almost 14\%) as ice wedge Oy7-11 IW7 (7\%). This suggests that width may be one determining factor, as ice wedges Oy7-04 IW2 and Oy711 IW1 were about $3.5 \mathrm{~m}$ wide whereas ice wedge Oy7-11 IW7 was only $2.5 \mathrm{~m}$ wide and, therefore, probably younger. In the $\delta^{18} \mathrm{O}$ class $-22 \%$ to $-22.99 \%$, Oy7-04 IW2 shows an elevated amount (8\%) compared to Oy7-11 IW1 and Oy7-11 IW7 with 2.5 per cent and 1 per cent, respectively. The remaining classes can be neglected since they contain very few samples.

These variations demonstrate that ice wedges are not uniform bodies but differ regarding frost cracking and icewedge growth. The incorporation of the precipitation isotope signal into an ice wedge has to be taken into account as well. From monitoring, Mackay (1992) revealed that ice-wedge cracking can be a temporally episodic process, depending on different factors including snowcover thickness. Beside climatically induced year to year differences in winter precipitation amount, seasonality, isotopic composition and frost intensity, local effects like non-uniform snow accumulation due to surface irregularities within the ice-wedge polygon or wind drift could have resulted in different frost-cracking frequencies for the studied ice wedges at different time slices. Another possible cause for the different isotopic distributions relates to which part of winter precipitation the ice veins contain. Meltwater from different stages of snow melt exhibits different isotope signatures due to progressive isotopic fractionation: initial meltwater shows more negative $\delta^{18} \mathrm{O}$ and higher $d$-excess values than that generated later (Lauriol et al., 1995). In addition, hoar frost or snow falling directly into the frost crack may contribute to ice-vein formation. Finally, the issue of sampling resolution is pertinent as one elementary ice vein may integrate several different precipitation events during one winter. In turn, one ice sample comprises some five to 20 ice veins and therefore represents a mixed signal of different cracking events at about a decadal resolution.

Even though micro-scale factors such as these may have an influence, similar general isotope characteristics (minima, mean, maxima, slope, Table 1) and similar features in the ice-wedge isotopic profiles (maxima, minima) lead to the conclusion that climate signals are present in variations of $\delta^{18} \mathrm{O}$ and $d$-excess data (Figure $5 \mathrm{a}-\mathrm{c}$ ). The profiles are characterised by a high variability, indicating that isotopic diffusion, which would smooth the record, probably did not take place in the ice wedges studied.

The $\delta^{18} \mathrm{O}$ profiles generally reflect the ice-wedge structure: the highest values (about $-23 \%$ to $-21 \%$ ) are found in the youngest ice-wedge parts directly below the assemblages of recent ice veins with similar $\delta^{18} \mathrm{O}$ values, 

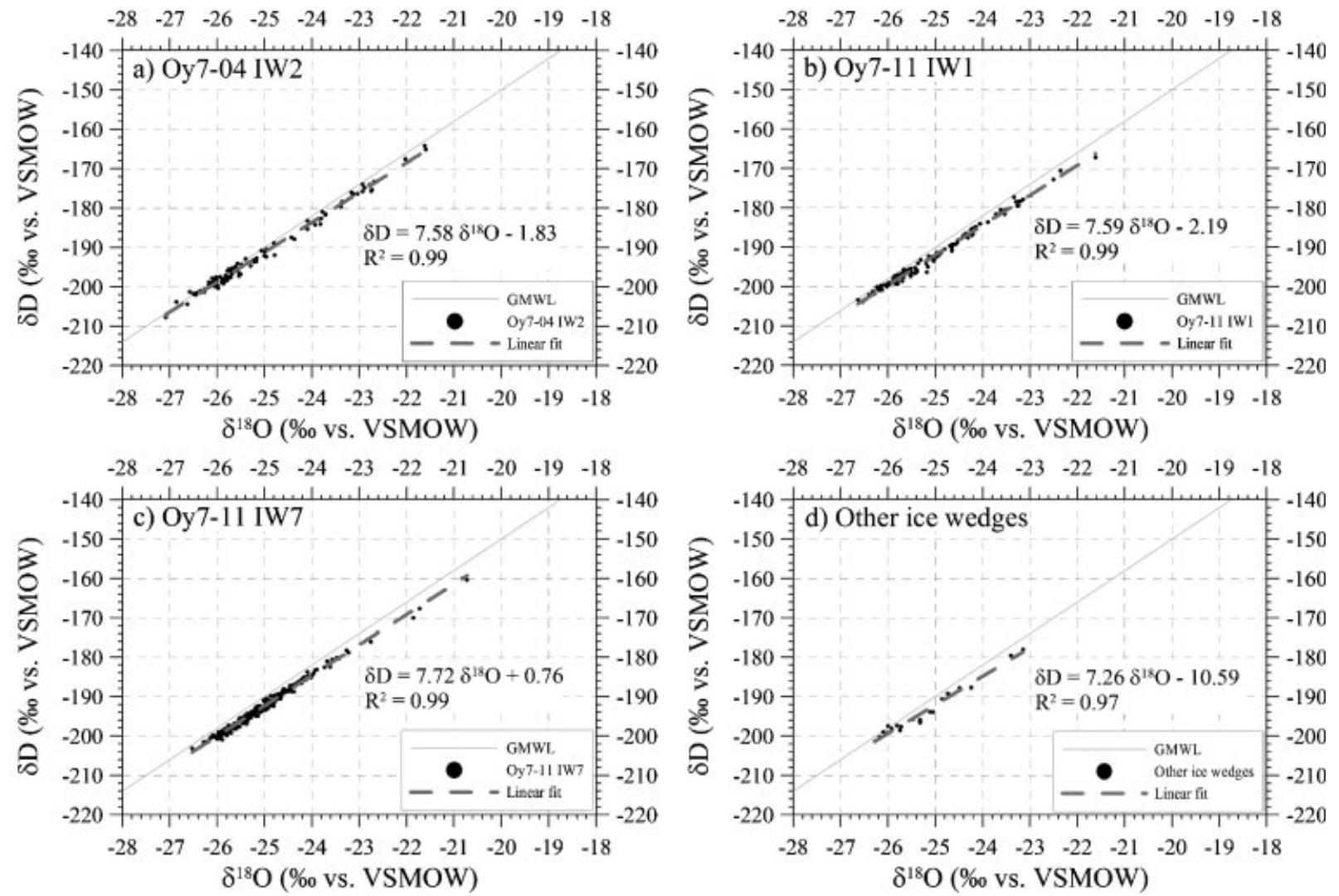

Figure $6 \quad \delta^{18} \mathrm{O}-\delta$ D diagrams for ice wedges (a) Oy7-04 IW 2, (b) Oy7-11 IW 1, (c), Oy7-11 IW 7 and (d) other Holocene ice wedges. Abbreviations as given in Figure 3.

confirming recent growth of ice wedges at the position of the studied profiles. The lowest values (about $-27 \%$ to $-25 \%$ ) are evident in the outer parts of the ice wedges. Ice wedges Oy7-04 IW2 and Oy7-11 IW7 exhibit generally symmetrical $\delta^{18} \mathrm{O}$ profiles, and apparently corresponding $\delta^{18} \mathrm{O}$ maxima are detectable on both sides of the central part, indicating symmetrical growth with frost cracking at a virtually constant location (Figure 5a and c).

The range of $\delta^{18} \mathrm{O}$ variation in the profiles is about 4 to $6 \%$. This is similar to values observed in Holocene alas ice wedges on Bol'shoy Lyakhovsky Island (Meyer et al., 2002b) and the Bykovsky Peninsula, the latter with more negative values overall (Meyer et al., 2002a); whereas at Cape Mamontov Klyk a variation of only about 3\% was observed (Meyer et al., unpublished data). Drawing on the attempts by Vasil'chuk (1992) and Nikolayev and Mikhalev (1995) to relate the $\delta^{18} \mathrm{O}$ range to absolute temperatures, which, however, were based only on sparse data, our data would indicate Late Holocene temperature variations of $9 \mathrm{~K}$ to $12 \mathrm{~K}$ for mean January temperatures and $6 \mathrm{~K}$ to $7 \mathrm{~K}$ for mean winter temperatures.

The most negative $\delta^{18} \mathrm{O}$ values ( $-27 \%$ to $-25 \%$ ) in the outer part of the profiles are similar to samples from lower and therefore older ice-wedge parts (other Holocene samples, Table 1). This indicates similar winter temperature conditions in the Late Holocene around 3500 a BP to 2500 a $\mathrm{BP}$ and in the initial phase of ice-wedge growth, probably in the Early Holocene after drainage of the thermokarst lake. The heaviest $\delta^{18} \mathrm{O}$ values $(-23 \%$ to $-21 \%$ ) of the profiles correspond well with values in recent ice wedges (mean: $-22 \%$ ). Therefore, we consider the highest values as representing recent conditions. Consequently, the $\delta^{18} \mathrm{O}$ data indicate a marked Late Holocene winter warming trend with several briefer temperature maxima and minima and a generally warmer last millennium. This is in contradiction to several other northern-hemisphere high-latitude palaeorecords, which show cooling trends during the last 6000 years (e.g. Wanner et al., 2008). However, Andreev et al. (2001) reconstructed a general warming trend since 1.5 to $1.7 \mathrm{ka}$ BP from pollen data in the nearby Yana lowland, interrupted by a temperature maximum at about $1 \mathrm{ka} \mathrm{BP}$ and a subsequent minimum at about $500 \mathrm{a}$ BP. These temperature patterns may correspond to known climate periods such as the Medieval Warm Period (MWP, about AD 900-1200) and the Little Ice Age (LIA, about AD 1300-1850) (e.g. Wanner et al., 2008). Similar features are also detectable in the icewedge profile $\delta^{18} \mathrm{O}$ data: the warm isotopic signal of sample Oy7-11-189 (-23\%) dated to 855 a BP (cal. AD 1118- 


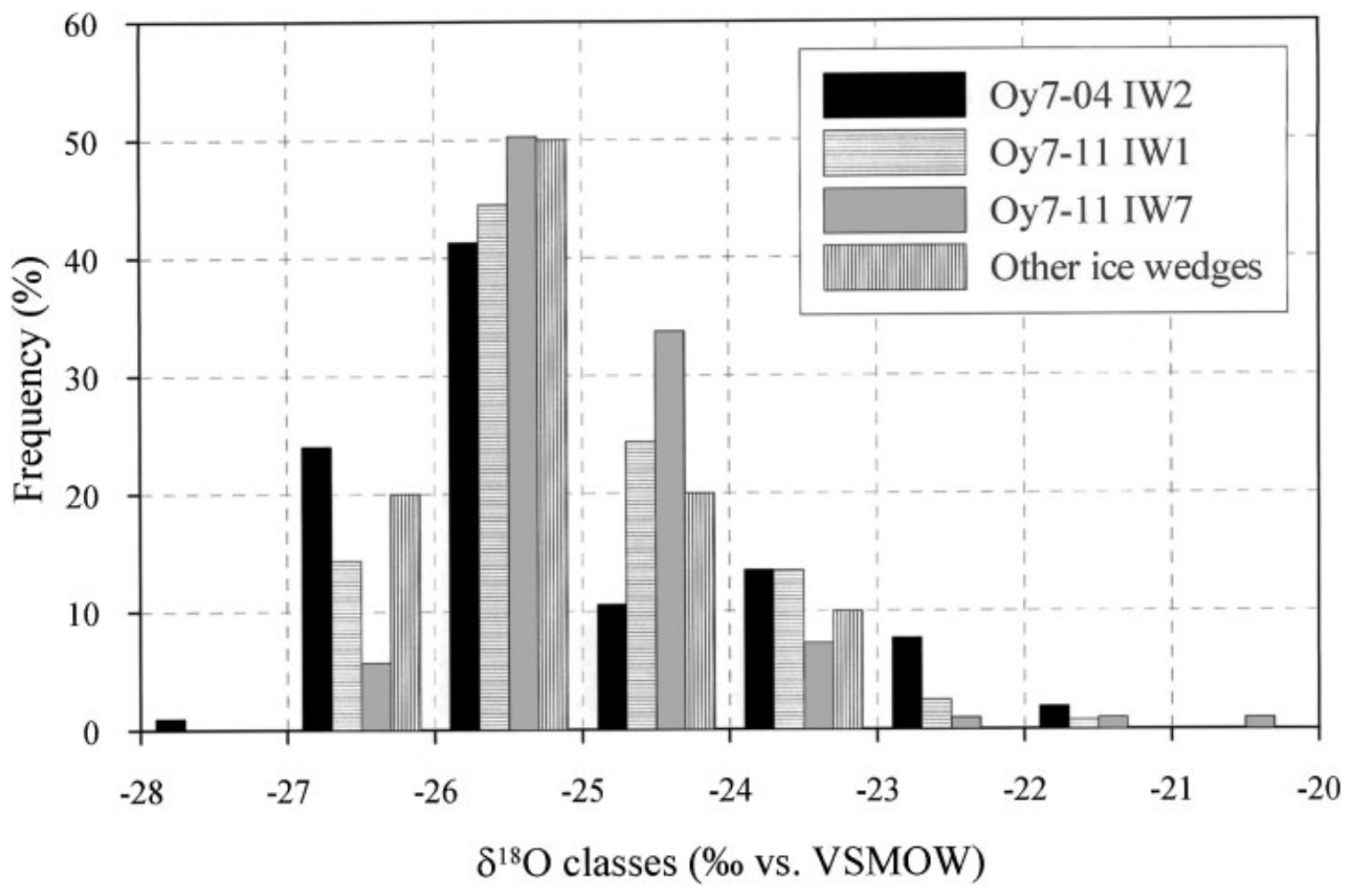

Figure 7 Frequency of $\delta^{18} \mathrm{O}$ values in classes for ice wedges Oy7-04 IW2, Oy7-11 IW1, Oy7-11 IW7 and other studied Holocene ice wedges. Abbreviation as given in Figure 3.

1264) may relate to the MWP. Three samples with low $\delta^{18} \mathrm{O}$ values $(-26 \%$ to $-25 \%$ ), dating to 525 a BP (cal. AD 1385-1449 AD, Oy7-04-242), 490 a BP (cal. AD 13841516, Oy7-04-267) and 260 a BP (cal. AD 1481-1684, Oy704-274) may relate to the LIA. However, the warm signal of sample Oy7-04-263 ( $\delta^{18} \mathrm{O}-22.7 \%$ ) dating to 410 a BP (cal. AD 1430-1520) would also fit into the time period of the LIA. Relatively little is known about the climate characteristics of these periods in northeast Siberia so the icewedge data from Oyogos Yar are particularly valuable in relation to winter temperatures during the last millennia. However, to verify these preliminary interpretations and to develop a continuous time series of Late Holocene winter temperatures, more absolute dating of ice-wedge samples would be needed.

The most recent parts of the high-resolution $\delta^{18} \mathrm{O}$ profiles, particularly those of ice wedge Oy7-11 IW7, reveal a pronounced maximum of $-22 \%$ to $-20.5 \%$ for the last several decades (approximately the last 30 to 50 years). The related rapid warming (increase of $4 \%$ o to $5 \%$ ) that led to the maximum might have taken place during the last 100 to 200 years, as it comprises only a few samples (Figure 5a-c). Similar strong warming in the Russian Arctic was recorded in the Akademii Nauk ice core (Severnaya Zemlya) from about AD 1800 to the 1930s (Fritzsche et al., 2005). The ice-wedge $\delta^{18} \mathrm{O}$ increase of about $4 \%$ to $5 \%$ may be interpreted as roughly equivalent to warming of $4 \mathrm{~K}$ to $6 \mathrm{~K}$ (winter temperature) and $6 \mathrm{~K}$ to $10 \mathrm{~K}$ (January temperature) (Vasil'chuk, 1992; Nikolayev and Mikhalev, 1995). No matter the degree of change, however, modern winter temperatures on the Oyogos Yar coast have clearly been the warmest of the Late Holocene and probably the warmest since the Early Holocene optimum.

The $d$-excess values of the ice-wedge profiles vary considerably and range between $5 \%$ and $11 \%$. They resemble the range observed in Holocene alas ice wedges on Bol'shoy Lyakhovsky Island (Meyer et al., 2002b), whereas similar wedges on the Bykovsky Peninsula (Meyer et al., 2002a) and at Cape Mamontov Klyk (Meyer et al., unpublished data) show distinctly higher values (about $8 \%$ to $18 \%$ ).

Values of $d$ excess and $\delta^{18} \mathrm{O}$ are inversely correlated (Oy704 IW2, r = -0.49; Oy7-11 IW1, r=-0.48; Oy7-11 IW7, $\mathrm{r}=-0.33$ ). The relatively weak correlations reflect different $d$-excess values on the two sides of the youngest ice-wedge parts (Figure 5a-c), which exhibit the lowermost $d$-excess values (about 5-6\%o), comparable to that of recent ice wedges (Table 1). On both sides of the youngest parts, shifts from higher to lower $d$-excess values and back again are present in the ice-wedge profiles (Figure 5a-c). They comprise short-term changes (based on one or two samples) in relation to more stable conditions represented by five to 
ten samples. Whereas the latter should be regarded as climate-related signals, short-term variations are more likely influenced by the secondary fractionation processes.

We assume that lower $d$-excess values represent a higher contribution of regional moisture (i.e. from the North Pacific or polynyas), whereas higher $d$-excess data point to a greater influence of Atlantic moisture. Consequently, changes in $d$-excess records point to varying proportions of these moisture sources throughout the last millennia. This contradicts Meyer (2003) who inferred that the North Pacific was a constant moisture source for nearby Bol'shoy Lyakhovsky Island to explain low $d$-excess values. However, kinetic fractionation due to sublimation/evaporation effects before and during melting and percolation of meltwater through the snowpack might also have contributed to the $d$ excess shift to relatively low values.

The low $d$-excess values in the youngest ice-wedge parts probably point to a significant contribution of regional moisture to winter precipitation on the Oyogos Yar coast in modern times. A recharge by continental surface water can be excluded due to its frozen state in winter. As mentioned above, possible sources for moisture generation at colder temperatures than those in the North Atlantic Ocean (leading to lower $d$-excess values) could be the North Pacific Ocean as well as the Laptev or East Siberian seas (see also Meyer et al., 2002b). Two main factors are assumed to control the contribution of regional moisture to winter precipitation: sea-ice extent and atmospheric circulation patterns. In winter, the Laptev and East Siberian seas are completely icecovered except for polynyas. Therefore, substantial changes in the extent of sea-ice cover could not have caused the higher proportion of regional moisture. However, larger polynyas or a later freeze-up of the Laptev and East Siberian seas could have provided more regional moisture in modern times. Another possibility is a change in atmospheric circulation patterns, in particular the dynamics of the Siberian High and the Aleutian Low. A strengthened Aleutian Low could have led to increased precipitation of regional moisture due to a higher frequency of cyclones. Together with the warmest $\delta^{18} \mathrm{O}$ data of the studied ice wedges, this higher proportion of regional moisture in the youngest ice-wedge parts is interpreted as a feature of recent Arctic warming.

\section{CONCLUSIONS}

Ice wedges in an alas at the Dmitrii Laptev Strait likely developed epigenetically in the Early Holocene after drainage of a thermokarst lake, and subsequently (since about 3500 years BP) they grew syngenetically and continue to crack.

Recently formed wedge ice exhibits an isotopic composition close to the GMWL, indicating that climate signals should be obtainable from ice wedges. Even though isotope values are differently distributed, high-resolution sampled Late Holocene ice-wedge profiles show similar isotopic composition (maximum, mean and minimum values as well as slope and intercept), leading to a significant LMWL for winter precipitation that differs only slightly from the GMWL.

This study is the first attempt to interpret high-resolution (1-3-cm sampling spacing) isotopic signals from Holocene ice wedges in terms of a climate record using AMS ${ }^{14} \mathrm{C}$ dating of organic matter incorporated within the ice. The effects of different processes involved in ice-wedge formation make climate interpretation difficult. However, $\delta^{18} \mathrm{O}$ data indicate considerable changes in winter temperatures in the Late Holocene with a warming trend through time. Superimposed on this trend is a marked variability that may reflect periods such as the MWP and LIA. The youngest ice-wedge parts from the last few decades to centuries exhibit the highest temperatures of the whole record, and these likely relate to recent Arctic climate change. The $d$ excess record exhibits a pronounced variability, probably caused by changing proportions of Atlantic Ocean, Pacific Ocean and polynya moisture in precipitation feeding the ice wedges studied on the Oyogos Yar coast.

\section{ACKNOWLEDGEMENTS}

This study is part of the Russian-German cooperative scientific project 'System Laptev Sea' and the International Polar Year project 'Past Permafrost' (IPY project 15). It was partly funded by the state of Berlin (NaFöG PhD scholarship and travel costs for Thomas Opel). We thank our Russian and German colleagues of the expedition 'Lena - New Siberian Islands 2007' for support during the fieldwork. Sampling and analytical work in the AWI Potsdam laboratories were greatly supported by Bernhard Chapligin, Antje Eulenburg and Lutz Schönicke. We thank the editor Antoni Lewkowicz, Rossana Raffi and an anonymous reviewer for constructive comments which helped to improve the quality of the manuscript.

\section{REFERENCES}

ACIA. 2005. Arctic Climate Impact Assessment. Cambridge University Press: Cambridge, New York, Melbourne, Madrid, Cape Town, Singapore, São Paulo; 1042 pp.

Andreev AA, Klimanov VA, Sulerzhitsky LD. 2001. Vegetation and climate history of the Yana River lowland, Russia, during the last 6400 yr. Quaternary Science Reviews 20: 259-266.

Andreev AA, Tarasov PE, Siegert C, Ebel T, Klimanov VA, Melles M, Bobrov AA, Dereviagin AYu, Lubinski DJ, Hubberten H-W. 2003. Late Pleistocene and Holocene vegetation and climate on the northern Taymyr Peninsula, Arctic Russia. Boreas 32: 484-505.

Andreev AA, Grosse G, Schirrmeister L, Kuznetsova TV, Kuzmina SA, Bobrov AA, Tarasov PE, Novenko EY, Meyer H, Derevyagin AY, Kienast F, Bryantseva A, Kunitsky VV. 2009. Weichselian and Holocene palaeoenvironmental history of the Bol'shoy Lyakhovsky Island, New Siberian Archipelago, Arctic Siberia. Boreas 38: 72-110. DOI: 10.1111/j.1502-3885.2008.00039.x 
Blinov A, Alfimov V, Beer J, Gilichinsky D, Schirrmeister L, Kholodov A, Nikolskiy P, Opel T, Tikhomirov D, Wetterich S. 2009. Ratio of ${ }^{36} \mathrm{Cl} / \mathrm{Cl}$ in ground ice of east Siberia and its application for chronometry. Geochemistry, Geophysics, Geosystems 10: Q0AA03. DOI: 10.1029/2009GC002548.

Bunge AA. 1887. Bericht über den ferneren Gang der Expedition. Reise nach den Neusibirischen Inseln. Aufenthalt auf der Grossen Ljachof-Insel. In Expedition nach den Neusibirischen Inseln und dem Jana-Lande (1885), Schrenk LV, Maximovicz CJ (eds). Beiträge zur Kenntnis des russischen Reiches und der angrenzenden Länder Asiens 3. Buchdruckerei der Kaiserlichen Academie der Wissenschaften: St Petersburg; 231-284.

Christensen JH, Hewitson B, Busuioc A, Chen A, Gao X, Held I, Jones R, Kolli RK, Kwon W-T, Laprise R, Magaña Rueda V, Mearns L, Menéndez CG, Räisänen J, Rinke A, Sarr A, Whetton P. 2007. Regional climate projections. In Climate Change 2007: The Physical Science Basis. Contribution of Working Group I to the Fourth Assessment Report of the Intergovernmental Panel on Climate Change, Solomon S, Qin D, Manning M, Chen Z, Marquis M, Averyt KB, Tignor M, Miller HL (eds). Cambridge University Press: Cambridge and New York; 847-940.

Craig H. 1961. Isotopic variations in meteoric waters. Science 133: 1702-1703.

Dansgaard W. 1964. Stable isotopes in precipitation. Tellus 16: 436-468.

Dereviagin AYu, Meyer $\mathrm{H}$, Chizhov AB, Hubberten H-W, Simonov EF. 2002. New data on the isotopic composition and evolution of modern ice edges in the Laptev Sea Region. Polarforschung 70: 27-35.

Fritzsche D, Schütt R, Meyer H, Miller H, Wilhelms F, Opel T, Savatyugin LM. 2005. A 275 year ice-core record from Akademii Nauk ice cap, Severnaya Zemlya, Russian Arctic. Annals of Glaciology 42: 361-366.

Gilichinsky DA, Nolte E, Basilyan AE, Beer J, Blinov AV, Lazarev VE, Kholodov AL, Meyer H, Nikolskiy PA, Schirrmeister L, Tumskoy VE. 2007. Dating of syngenetic ice wedges in permafrost with ${ }^{36} \mathrm{Cl}$. Quaternary Science Reviews 26: 547-1556. DOI:10.1016/j.quascirev.2007.04.004

Gravis GF. 1978. Tsiklichnost' termokarsta na Primorskoi nizmenosti v verkhnem Pleistotsene i Golotsene (Cyclicity of thermokarst at the coastal lowlands during the late Pleistocene and Holocene). In Third International Conference on Permafrost, Proceedings, Edmonton, Alberta, Canada. Vol. 1: 283-287 (in Russian).

Henderson KA. 2002. An ice core paleoclimate study of Windy Dome, Franz Josef Land (Russia): development of a recent climate history for the Barents Sea. PhD dissertation, Ohio State University, USA.

Ilyashuk BP, Andreev AA, Bobrov AA, Tumskoy VE, Ilyashuk EA. 2006. Interglacial history of a palaeo-lake and regional environment: A multi-proxy study of a permafrost deposit from Bol'shoi Lyakhovsky Island, Arctic Siberia. Journal of Paleolimnology 35: 855-872.

Kienast F, Tarasov P, Schirrmeister L, Grosse G, Andreev AA. 2008. Continental climate in the East Siberian Arctic during the last interglacial: implications from palaeobotanical records. Global and Planetary Change 60: 535-562.

Kloss AL. 2008. Water isotope geochemistry of recent precipitation in Central and North Siberia as a proxy for the local and regional climate system. Unpublished diploma thesis, Insti- tute for Physical Geography and Landscape Ecology, Leibniz University of Hannover, Germany.

Konishchev VN, Kolesnikov SF. 1981. Osobennosti stroeniya i sostava pozdnekainozoiskikh otlozheniyakh b obnazhenii Oyagosskii Yar (Specifics of structure and composition of late Cenozoic deposits in the section of Oyogossky Yar). In Problemy Kriolitologii (Problems of Cryolithology) Vol. IX, Popov AI (ed.) Moscow University Press: Moscow; 107-117 (in Russian).

Kurita N, Yoshida N, Inoue G, Chayanova EA. 2004. Modern isotope climatology of Russia: a first assessment. Journal of Geophysical Research 109: D03102. DOI: 10.1029/ 2003JD003404

Kurita N, Sugimoto A, Fujii Y, Fukazawa T, Makarov VN, Watanabe O, Ichiyanagi K, Numaguti A, Yoshida N. 2005. Isotopic composition and origin of snow over Siberia. Journal of Geophysical Research 110: D13102. DOI:10.1029/ 2004JD005053

Kuznetsova LP. 1998. Atmospheric moisture content and transfer over the territory of the former USSR. In Second International Workshop on Energy and Water Cycle in GAMESiberia, 1997, Ohata T, Hiyama T (eds). Research Report of IHAS. Institute for Hydrospheric-Atmospheric Sciences, Nagoya University: Nagoya, Japan; 145-151.

Lachenbruch AH. 1962. Mechanics of thermal construction cracks and ice wedge polygons in permafrost. Geological Society of America. Special Paper 70.

Lauriol B, Duchesne C, Clark ID. 1995. Systématique du remplissage en eau des fentes de gel: les réesultats d'une étude oxygéne-18 et deutérium. Permafrost and Periglacial Processes 6: 47-55.

Lemke P, Ren J, Alley RB, Allison I, Carrasco J, Flato G, Fujii Y, Kaser G, Mote P, Thomas RH, Zhang T. 2007. Observations: Changes in snow, ice and frozen ground. In Climate Change 2007: The Physical Science Basis. Contribution of Working Group I to the Fourth Assessment Report of the Intergovernmental Panel on Climate Change, Solomon S, Qin D, Manning M, Chen Z, Marquis M, Averyt KB, Tignor M, Miller HL (eds). Cambridge University Press: Cambridge and New York; 337-383.

Lewkowicz AG. 1994. Ice-wedge rejuvenation, Fosheim Peninsula, Ellesmere Island, Canada. Permafrost and Periglacial Processes 5: 251-268.

Mackay JR. 1974. Ice-wedge cracks, Garry Island, Northwest Territories. Canadian Journal of Earth Sciences 11: 13661383.

Mackay JR. 1983. Oxygen isotope variations in permafrost, Tuktoyaktuk Peninsula area, Northwest Territories. Current Research, Part B, Geological Survey of Canada Paper 83-1B: 67-74.

Mackay JR. 1992. The frequency of ice-wedge cracking (19671987) at Garry Island, western Arctic coast, Canada. Canadian Journal of Earth Sciences 29: 236-248.

Meyer H. 2003. Late Quaternary climate history of Northern Siberia - evidence from ground ice. Reports on Polar and Marine Research 461. Alfred Wegener Institute for Polar and Marine Research: Bremerhaven; 1-111.

Meyer H, Schönicke L, Wand U, Hubberten H-W. 2000. Isotope studies of hydrogen and oxygen in ground ice - experiences with the equilibration technique. Isotopes in Environmental and Health Studies 36: 133-149.

Meyer H, Dereviagin AYu, Siegert C, Hubberten H-W. 2002a. Paleoclimate studies on Bykovsky Peninsula, North Siberia - 
Hydrogen and oxygen isotopes in ground ice. Polarforschung 70: $37-51$.

Meyer H, Dereviagin AYu, Siegert C, Schirrmeister L, Hubberten H-W. 2002b. Paleoclimate reconstruction on Big Lyakhovsky Island, North Siberia - Hydrogen and oxygen isotopes in ice wedges. Permafrost and Periglacial Processes 13: 91-105. DOI: 10.1002/ppp.416.

Meyer H, Schirrmeister L, Yoshikawa K, Opel T, Wetterich S, Hubberten H-W, Brown J. Accepted. Permafrost evidence for severe winter cooling during the Younger Dryas in northern Alaska. Geophysical Research Letters.

Michel FA. 1982. Isotope investigations of permafrost waters in northern Canada. PhD thesis, Department of Earth Sciences, University of Waterloo, Canada.

Nadeau MJ, Schleicher M, Grootes PM, Erlenkeuser H, Gottdang A, Mous DJW, Sarnthein JM, Willkomm H. 1997. The Leibniz Labor facility at the Christian-Albrechts-University, Kiel, Germany. Nuclear Instruments and Methods in Physics Research B123: 22-30.

Nadeau MJ, Grootes PM, Schleicher M, Hasselberg P, Rieck A, Bitterling M. 1998. Sample throughput and data quality at the Leibniz Labor AMS facility. Radiocarbon 40: 239-245.

Naurzbaev MM, Vaganov EA, Sidorova OV, Schweingruber FH. 2002. Summer temperatures in eastern Taimyr inferred from a 2427-year late-Holocene tree-ring chronology and earlier floating series. The Holocene 12(6): 727-736.

Nikolayev VI, Mikhalev DV. 1995. An oxygen-isotope paleothermometer from ice in Siberian permafrost. Quaternary Research 43(1): 14-21.

North Greenland Ice Core Project (NorthGRIP) Members. 2004. High-resolution record of Northern Hemisphere climate extending into the last interglacial period. Nature 431(7005): 147-151.

Opel T, Fritzsche D, Meyer H, Schütt R, Weiler K, Ruth U, Wilhelms F, Fischer H. 2009. 115 year ice-core data from Akademii Nauk ice cap, Severnaya Zemlya: high-resolution record of Eurasian Arctic climate change. Journal of Glaciology 55(189): 21-31.

Polyakov IV, Bekryaev RV, Alekseev GV, Bhatt US, Colony RL, Johnson MA, Maskshtas AP, Walsh D. 2003. Variability and trends of air temperature and pressure in the maritime Arctic, 1875-2000. Journal of Climate 16(12): 20672077.

Raab A, Melles M, Berger GW, Hagedorn B, Hubberten H-W. 2003. Non-glacial paleoenvironments and the extent of Weichselian ice sheets on Severnaya Zemlya, Russian High Arctic. Quaternary Science Reviews 22: 2267-2283.

Reimer PJ, Baillie MGL, Bard E, Bayliss A, Beck JW, Bertrand CJH, Blackwell PG, Buck CE, Burr GS, Cutler KB, Damon PE, Edwards RL, Fairbanks RG, Friedrich M, Guilderson TP, Hogg AG, Hughen KA, Kromer B, McCormac G, Manning S, Ramsey CB, Reimer RW, Remmele S, Southon JR, Stuiver M, Talamo S, Taylor FW, van der Pflicht J, Weyhenmeyer CE. 2004. INTCAL04 terrestrial radiocarbon age calibration, 0-26 cal kyr BP. Radiocarbon 46: 1029-1058.

Rozanski K, Araguás-Araguás L, Gonfiantini R. 1993. Isotopic patterns in modern global precipitation. In Climate Change in Continental Isotopic Records, Swart PK, Lohmann KC, McKenzie J, Savin S (eds). Geophysical Monograph No 78. American Geophysical Union: Washington; 1-36.

Schirrmeister L, Grosse G, Kunitsky V, Meyer H, Derivyagin A, Kuznetsova T. 2003. Permafrost, periglacial and paleoenvironmental studies on New Siberian Islands. In Rus-
sian-German Cooperation System Laptev Sea The Expeditions Lena 2002, Grigoriev MN, Rachold V, Bolshiyanov DYu, Pfeiffer EM, Schirrmeister L, Wagner D, Hubberten HW (eds). Reports on Polar and Marine Research 466. Alfred Wegener Institute for Polar and Marine Research: Bremerhaven; 195-314.

Schirrmeister L, Wetterich S, Kunitsky V, Tumskoy V, Dobrynin D, Derevyagyn A, Opel T, Kienast F, Kuznetsova T, Gorodinski A. 2008. Palaeoenviromental studies on the Oyogos Yar coast. In The Expedition LENA - NEW SIBERIAN ISLANDS 2007 during the International Polar Year (IPY) 2007/2008, Boike J, Bol'shiyanov DY, Schirrmeister L, Wetterich S (eds). Reports on Polar and Marine Research 584. Alfred Wegener Institute for Polar and Marine Research: Bremerhaven; 85-154.

Shur Y, Hinkel KM, Nelson FE. 2005. The transient layer: implications for geocryology and climate-change science. Permafrost and Periglacial Processes 16: 5-17. DOI: 10.1002/ppp.518

Stuiver M, Polach HA. 1977. Discussion: Reporting of ${ }^{14} \mathrm{C}$ data. Radiocarbon 19: 355-363.

Trenberth KE, Jones PD, Ambenje P, Bojariu R, Easterling D, Klein Tank A, Parker D, Rahimzadeh F, Renwick JA, Rusticucci M, Soden B, Zhai P. 2007. Observations: Surface and atmospheric climate change. In Climate Change 2007: The Physical Science Basis. Contribution of Working Group I to the Fourth Assessment Report of the Intergovernmental Panel on Climate Change, Solomon S, Qin D, Manning M, Chen Z, Marquis M, Averyt KB, Tignor M, Miller HL (eds). Cambridge University Press: Cambridge and New York; 237-336.

Vaikmäe R. 1989. Oxygen isotopes in permafrost and ground ice - a new tool for paleoclimatic investigations. In $5^{\text {th }}$ Working Meeting 'Isotopes in Nature', Proceedings. Leipzig, Germany; 543-553.

van Everdingen R (ed.) 1998. revised 2005. Multi-language Glossary of Permafrost and Related Ground-ice Terms. National Snow and Ice Data Center/World Data Center for Glaciology: Boulder, CO.

Vasil'chuk YuK. 1991. Reconstruction of the palaeoclimate of the late Pleistocene and Holocene on the basis of isotope studies of subsurface ice and waters of the permafrost zone. Water Resources 17(6): 640-674.

Vasil'chuk YuK. 1992. Oxygen Isotope Composition of Ground Ice. Application to Paleogeocryological Reconstructions. Geological Faculty of Moscow State University, Russian Academy of Sciences: Moscow; (in Russian).

Vasil'chuk YuK, van der Plicht J, Jungner H, Sonninen E, Vasil'chuk AC. 2000. First direct dating of Late Pleistocene ice-wedges by AMS. Earth and Planetary Science Letters 179: 237-242.

von Toll EV. 1895. Wissenschaftliche Resultate der von der Kaiserlichen Akademie der Wissenschaften zur Erforschung des Janalandes und der Neusibirischen Inseln in den Jahren 1885 und 1886 ausgesandten Expedition. Abtheilung 3. Die fossilen Eislager und ihre Beziehungen zu den Mammuthleichen. Mémoires de L'Académie impérials des Sciences de St. Pétersbourg VII Série, Tome XLII, No. 13. Commissionnaires de I'Académie Impériale des Sciences: St Pétersbourg; $1-86$.

Wanner H, Beer J, Bütikofer J, Crowley TJ, Cubasch U, Flückiger J, Goosse H, Grosjean M, Joos F, Kaplan JO, Küttel M, Müller SA, Prentice IC, Solomina O, Stocker 
Palaeoclimatic Information from Stable Isotopes of Holocene Ice Wedges

TF, Tarasov P, Wagner M, Widmann M. 2008. Mid- to Late Holocene climate change: an overview. Quaternary Science Reviews 27: 1791-1828. DOI:10.1016/j.quascirev. 2008.06.013

Wetterich S, Schirrmeister L, Andreev AA, Pudenz M, Plessen B, Meyer H, Kunitsky VV. 2009. Eemian and Late Glacial/
Holocene palaeoenvironmental records from permafrost sequences at the Dmitry Laptev Strait (NE Siberia, Russia). Palaeogeography Palaeoclimatology Palaeoecology 279: 73-95. DOI:10.1016/j.palaeo.2009.05.002

Yershov ED (ed.) 1989. Geocryology of the USSR, Vol. Eastern Siberia and Far East. Nedra: Moscow; (in Russian). 